\title{
Food Quantity and Quality
} Interactions at

\section{Phytoplankton-Zooplankton Interface: Chemical and Reproductive Responses in a Calanoid Copepod}

Rong $\mathrm{Bi}^{1,2,3 *}$ and Ulrich Sommer ${ }^{2}$

' Frontiers Science Center for Deep Ocean Multispheres and Earth System, and Key Laboratory of Marine Chemistry Theory and Technology, Ministry of Education, Ocean University of China, Qingdao, China, ${ }^{2}$ Marine Ecology, GEOMAR Helmholtz Center for Ocean Research Kiel, Kiel, Germany, ${ }^{3}$ Laboratory for Marine Ecology and Environmental Science, Qingdao National Laboratory for Marine Science and Technology, Qingdao, China

Marine food webs form the major component of the biological pump and play a central role in the global carbon (C) cycle. Understanding the response of particular processes in marine food webs to changing environments is a prerequisite to predict changes in ecological functioning in the future ocean. Here, we experimentally assessed the effects of nitrogen:phosphorus (N:P) supply ratios (the molar ratios 10:1, 24:1, and 63:1) on elemental and biochemical quality of marine phytoplankton Rhodomonas sp., and the interactions between food quantity and quality on stoichiometric C:N:P, fatty acids (FAs) and reproductions in copepods Acartia tonsa. Overall, the stoichiometry of $A$. tonsa was to some extent homeostatic in response to the changing algal $\mathrm{C}: \mathrm{N}$ and $\mathrm{C}: \mathrm{P}$ ratios, with significant changes in $\mathrm{C}: \mathrm{N}$ ratios of $A$. tonsa observed, especially under higher food quantities. The relative gross growth efficiencies (GGEs) for $C$ and $N$ (and $P$ ) were analyzed, revealing that copepods may achieve homeostasis by lowering the GGE for $\mathrm{C}$ while increasing it for the limiting nutrient. Egg production rates in $A$. tonsa were lowest on nutrient deficient diets under low food quantities. Reduced egg production rates may be attributed to the lowered GGEs for $C$ and reduced transfer efficiency of essential FAs between phytoplankton and copepods, indicating interactive-essential effects of elements and FAs on copepod production. Our results highlight that nutrient deficiency in the environments may reduce energy transfer efficiency at the base of food webs by altering phytoplankton chemical composition, which can interact with food quantity and have implications on food web dynamics in the changing ocean.

Keywords: food webs, food concentration, nutritional quality, stoichiometry, fatty acids, egg production, nutrient limitation 


\section{INTRODUCTION}

The pelagic food webs play a fundamental role in the biological pump and contribute substantially to carbon sequestration in the ocean (Passow and Carlson, 2012). Global climate change has exerted profound and complex impacts on marine food webs (Sommer et al., 2002; Edwards and Richardson, 2004; Lewandowska et al., 2014). For example, primary production, zooplankton abundance and fish stock recruitment in the North Sea have declined over 25 years and this has been driven primarily by a decrease in riverine nutrient inputs; the reduction in nutrient inputs caused a decline in primary production which was mirrored by a decline in small copepod abundance, revealing bottom-up control of herbivorous zooplankton by phytoplankton production (Capuzzo et al., 2018). In the central Baltic Sea in summer, zooplankton become more carnivorous under nutrient depletion (Loick-Wilde et al., 2019), because small ( $<5 \mu \mathrm{m})$ phytoplankton (generally favored by low nutrients) and $\mathrm{N}_{2}$-fixing cyanobacteria are outside the optimal food size range of herbivorous zooplankton (Sommer et al., 2002). Thus, the structure of marine pelagic food webs differs at different levels of nutrient richness (Sommer et al., 2002). Understanding the responses of marine food webs to environmental changes is therefore of critical importance to predict the structure and functioning of marine ecosystems under future ocean scenarios.

Phytoplankton and crustacean zooplankton (zooplankton hereafter) occupy a key ecological position in marine food webs as they constitute the crucial link of energy and substance transport to higher trophic levels (Harris et al., 2000). Ocean environmental changes have caused pronounced changes in phytoplankton biomass (Boyce et al., 2010; Lotze et al., 2019) and chemical composition (Galbraith and Martiny, 2015; Bi et al., 2017, 2018; Ruess and Müller-Navarra, 2019), altering the quantity and quality of phytoplankton as a food for consumers. While food quantity has long time been acknowledged as a limiting factor for consumers, limitation by food quality became an issue since ca. 25 years ago (Sommer, 1992; Urabe and Watanabe, 1992; Müller-Navarra et al., 2000; Boersma et al., 2008). Sterner and Schulz (1998) pioneered the integration of food quantity and quality aspect in regulating zooplankton nutrition, showing that zooplankton growth rate in response to food quantity differs under distinct scenarios of food quality. To date, studies on the interactive effects of food quantity and quality have been mostly performed with freshwater zooplankton (e.g., Amarasinghe et al., 1997; Boersma and Kreutzer, 2002; Schälicke et al., 2019), while little is known for marine zooplankton (but see Ambler, 1986; Koski et al., 2010).

Food quantity is conventionally measured in terms of carbon (C) absolute concentration (Sterner and Robinson, 1994), and food quality is primarily determined by the chemical match between phytoplankton elemental and biochemical composition and zooplankton demands (Müller-Navarra, 2008). Elemental quality of food is frequently expressed as elemental stoichiometry (Anderson et al., 2004; Hessen, 2008). Of all biochemical indicators of food quality, fatty acids (FAs) have attracted particular interest (Müller-Navarra et al., 2004; Ruess and MüllerNavarra, 2019). Essential FAs (EFAs) cannot be synthesized by consumers, or the synthesis rate is not sufficient to meet the basic biochemical needs of consumers (Arts et al., 2001; Kainz et al., 2004), and thus must be acquired through diet. $\omega 3$ and $\omega 6$-polyunsaturated FAs (PUFAs) such as eicosapentaenoic acid (20:5n-3; EPA) and docosahexaenoic acid (22:6n-3; DHA) are essential for animals and have received intense attention (Müller-Navarra, 2008; Parrish, 2009; Taipale et al., 2011; Ilić et al., 2019). There is evidence for the significance of phytoplankton elemental stoichiometry or EFAs in regulating marine zooplankton growth (Malzahn and Boersma, 2012; Diez et al., 2013), egg production (Augustin and Boersma, 2006; Jónasdóttir et al., 2009; Franco-Santos et al., 2018), development rate (Marja et al., 1998; Malzahn et al., 2010; Mathews et al., 2018), feeding behavior (Meunier et al., 2016), and movement patterns (Herstoff et al., 2019). The relative importance of elemental versus biochemical quality of food is a long-standing controversy which has attracted more attention in limnology than in marine ecology (Lampert, 2009), some studies proposing the primary control of elemental quality (e.g., Hessen, 1992; Boersma, 2000; Becker and Boersma, 2005; Malzahn and Boersma, 2012) but the others emphasizing the importance of FA availability in zooplankton nutrition (e.g., Brett, 1993; Müller-Navarra, 1995; Park et al., 2002; Ravet and Brett, 2006; Li et al., 2019). So far, little effort has been invested to simultaneously deal with food quantity and quality effects, and particularly to incorporate elemental and biochemical quality of food as limiting factors in the study of zooplankton production in the changing environments.

In the present study, we investigated the transfer of elements $[\mathrm{C}$, nitrogen $(\mathrm{N})$ and phosphorus $(\mathrm{P})]$ and EFAs ( $\omega 3$ - and $\omega 6$ PUFAs, in particular EPA and DHA) from marine phytoplankton to copepods, and egg production rates and nucleic acid ratios (RNA:DNA) of copepods under different food quantity and nutritional quality scenarios. The measurement of egg production rate is the most common technique to estimate zooplankton growth (Runge and Roff, 2000), while RNA:DNA has become a useful tool for zooplankton growth assessment, because of the primary function of RNA in protein synthesis (Saiz et al., 1998; Gorokhova, 2003; Gusmão and McKinnon, 2011; Yebra et al., 2017). We applied stoichiometric models to test the responses of the relative gross growth efficiencies (GGEs) for elements to different food quantity and nutritional quality (Anderson and Hessen, 1995), as well as the strength of limitation of elements versus EPA (and DHA) under nutrient deficient conditions (Anderson and Pond, 2000). Also, the relative trophic transfer efficiencies of EFAs versus $C$ can be assessed by comparing the relative EFA contents of phytoplankton and copepods (Brett and Müller-Navarra, 1997; Gladyshev et al., 2011; Pommier et al., 2012). The calanoid copepod Acartia tonsa was chosen as the model species for our study. The adults of this species do not build up large energy storage pools but rather invest most assimilated energy directly into egg production and thus respond quickly to altered feeding conditions with changed egg production (<24 h) (Dagg, 1977; Kiørboe et al., 1985). Food quality in this study is expressed as elemental stoichiometry (C:N and $\mathrm{C}: \mathrm{P}$ ) and carbon-normalized contents of EFAs in the cryptophyte Rhodomonas sp. under a wide range of N:P supply 
ratios and growth rates (dilution rates). Our study aims to test the following questions:

(1) How homeostatic is the stoichiometry of A. tonsa under different algal C:N and C:P? Does homeostasis depend on food quantity, and can it be achieved by increasing the GGE for the limiting nutrient or by lowering it for $\mathrm{C}$ ?

(2) Is nutrient deficiency the ultimate cause and FA deficiency the proximate cause of changes in egg production?

(3) Do the costs of homeostasis reduce egg production under nutrient deficiency? Is this effect different under low and high food quantities?

\section{MATERIALS AND METHODS}

\section{Phytoplankton Cultures}

The cryptophyte Rhodomonas sp. originated from the Kiel Bight, Baltic Sea. The cultures were maintained in sterile filtered natural seawater (Sterilizing Grade Filter, Sartobran P $0.2 \mu \mathrm{m}$; Sartorius Stedim Biotech GmbH, Göttingen, Germany), with additional macronutrients and micronutrients based on the modified Provasoli's culture medium (Provasoli, 1963; Ismar et al., 2008). The algae were grown at $18^{\circ} \mathrm{C}$ and a salinity of $18 \mathrm{psu}$ in a temperature-controlled room, with constant light intensity at $100 \mu \mathrm{mol}$ photons $\mathrm{m}^{-2} \mathrm{~s}^{-1}$ at a light:dark cycle of 16:8 h. Algal cultures were kept in $1 \mathrm{~L}$ Erlenmeyer flasks with $500 \mathrm{~mL}$ culture volume. All flasks were aerated slightly with filtered air and agitated manually twice per day at a set time.

Around 20 days prior to the copepod feeding experiment, batch cultures of Rhodomonas sp. were started under three N:P supply ratios ( $\mathrm{N}$ deficiency: $\mathrm{N}: \mathrm{P}=10: 1 \mathrm{~mol} \mathrm{~mol}^{-1}, 352 \mu \mathrm{mol}$ $\mathrm{L}^{-1}$ for $\mathrm{N}$ and $36 \mu \mathrm{mol} \mathrm{L} \mathrm{L}^{-1}$ for $\mathrm{P}$; balanced nutrient condition: $\mathrm{N}: \mathrm{P}=24: 1 \mathrm{~mol} \mathrm{~mol}^{-1}, 880 \mu \mathrm{mol} \mathrm{L}{ }^{-1}$ for $\mathrm{N}$ and $36 \mu \mathrm{mol} \mathrm{L}^{-1}$ for P; P deficiency: $\mathrm{N}: \mathrm{P}=63: 1 \mathrm{~mol} \mathrm{~mol}^{-1}, 880 \mu \mathrm{mol} \mathrm{L}{ }^{-1}$ for $\mathrm{N}$, and $14 \mu \mathrm{mol} \mathrm{L} \mathrm{L}^{-1}$ for $\mathrm{P}$ ). Background concentrations of $\mathrm{N}$ and $\mathrm{P}$ in natural seawater were very low and thus negligible. The N:P molar ratio of 24:1 instead of canonical 16:1 was considered balanced, consistent with the setup of $\mathrm{N}: \mathrm{P}$ ratio in the common and widely used f/2 medium (Guillard, 1975). The $\mathrm{N}: \mathrm{P}$ ratios of $10: 1$ and $63: 1$ were chosen to cover the typical ranges of $\mathrm{N}: \mathrm{P}$ in the ocean, including coastal and eutrophic regions (Downing, 1997). The observed maximal growth rate ( $\mu_{\max }, \mathrm{d}^{-1}$ ) was calculated from cell number changes during the exponential growth phase. Cell density was determined daily and subsequently transformed logarithmically. The linear increasing part in log plot of cell density was defined as the exponential phase. Once batch cultures reached the early stationary phase, semi-continuous cultures were started with two specific growth rates, $20 \%$ of $\mu_{\max }$ for $\mathrm{N}$ and $\mathrm{P}$ deficiency, and $80 \%$ of $\mu_{\max }$ for the balanced nutrient condition. Three food quality treatments were determined according to our previous studies (Bi et al., 2012, 2014). Briefly, we observed the lowest N:P biomass ratios in Rhodomonas sp. under $\mathrm{N}$ deficiency and $20 \%$ of $\mu_{\max }$, the intermediate values under the balanced nutrient condition and $80 \%$ of $\mu_{\max }$, and the highest ones under $\mathrm{P}$ deficiency and $20 \%$ of $\mu_{\max }$ (Bi et al., 2012). Moreover, PUFA contents in
Rhodomonas sp. were higher under $\mathrm{N}$ deficiency and low growth rates compared to those under $\mathrm{P}$ deficiency and balanced nutrient condition (Bi et al., 2014).

Semi-continuous cultures were conducted three times corresponding to the three runs of copepod chemical response experiments. Each treatment was run with two or three replicates. The outflows of semi-continuous cultures were daily supplied to copepods as food. Before feeding copepods, food suspensions from replicate flasks were pooled. Thus, copepod feeding was not influenced by variance between the algal culture replicates and copepod replicates received identical food.

\section{General Procedure of Copepod Cultures}

The copepod A. tonsa isolated from the Kiel Bight was obtained from the Department of Biology, Institute for Hydrobiology and Fisheries Science at the University of Hamburg and kept in our laboratory at the Helmholtz Centre for Ocean Research Kiel (GEOMAR) for more than three generations. The copepods were routinely fed Rhodomonas sp. grown under the balanced nutrient condition. The eggs of $A$. tonsa were stored in seawater at $4^{\circ} \mathrm{C}$ for later use, and those used in the experiments were not older than 3 months. It has been observed that $A$. tonsa eggs retain a high viability for up to 1 year at cold storage of $2-3^{\circ} \mathrm{C}$ (Drillet et al., 2006).

To initiate the experiments, a batch of eggs was incubated in filtered natural seawater. Copepod cultures were maintained under the same ambient conditions and culture medium as those in their diet throughout the experiment. The copepods were fed ad libitum Rhodomonas sp. until the cohort reached the copepodite V-VI stages. Developmental stage of copepods was identified using a ZEISS Discovery V.8 microscope.

\section{Experiments of Copepod Chemical Composition Response}

To test the effects of food quantity and quality on copepod chemical composition, we ran experiments using the algae from semi-continuous cultures. Six gradients of food quantities were set for each of the three food quality treatments (Table 1). Copepods were placed in $1 \mathrm{~L}$ Erlenmeyer flasks with $800 \mathrm{~mL}$ culture volume under different food treatments at an approximate density of 500 individuals $\mathrm{L}^{-1}$. This density is within the range of observed natural copepod aggregations in the ocean (Haury and Yamazaki, 1995; Mauchline, 1998). The initial densities were set as approximately 190 individuals needed for various chemical analyses and subsequent experiments with an estimated average mortality rate of 15 to $20 \% \mathrm{~d}^{-1}$. Three experimental runs were conducted to cover the wide range of food quantity in each food quality treatment. Duplicates of each food treatment were established. All culture flasks were aerated slightly with filtered air and carefully agitated twice per day at a set time.

Copepods were acclimated to different food treatments for 4 days prior to further measurements. During the acclimation period, the food was renewed daily to ensure that food quality remained constant. Initial food concentrations were calculated from the corresponding nominal algal concentrations and algal 
TABLE 1 | Initial food concentrations (calculated from the corresponding nomina initial food concentrations and algal carbon contents; $\mu \mathrm{g} \mathrm{C} \mathrm{L}^{-1}$ ) under different food quantity and quality treatments [the balanced and fast growth diet $(80 \%$ of $\left.\mu_{\max }\right)$, and $\mathrm{N}$ - and P-deficient and slow growth diet (20\% of $\left.\left.\mu_{\max }\right)\right]$ in copepod chemical response experiments and egg production rate experiments.

\begin{tabular}{|c|c|c|c|}
\hline & \multicolumn{3}{|c|}{ Initial food concentration } \\
\hline & $\begin{array}{c}\text { N deficiency } \\
20 \% \mu_{\max }\end{array}$ & $\begin{array}{l}\text { P deficiency } \\
20 \% \mu_{\max }\end{array}$ & $\begin{array}{l}\text { Balanced N:P } \\
80 \% \mu_{\max }\end{array}$ \\
\hline \multirow{6}{*}{$\begin{array}{l}\text { Chemical response } \\
\text { experiments }\end{array}$} & $41.6^{a}$ & $41.9^{a}$ & $29.9^{b}$ \\
\hline & $114.6^{b}$ & $133.9^{b}$ & $59.8^{b}$ \\
\hline & $237.9^{c}$ & $278.0^{c}$ & $176.9^{c}$ \\
\hline & $415.8^{a}$ & $419.2^{a}$ & $314.4^{a}$ \\
\hline & $916.5^{\mathrm{b}}$ & $1059.6^{b}$ & $1257.8^{a}$ \\
\hline & $2079.2^{a}$ & $2096.1^{a}$ & $1914.5^{b}$ \\
\hline \multirow{2}{*}{$\begin{array}{l}\text { Egg production rate } \\
\text { experiments }{ }^{a}\end{array}$} & 415.8 & 419.2 & 314.4 \\
\hline & 2079.2 & 2096.1 & 1257.8 \\
\hline
\end{tabular}

a,b,c Copepods were fed the diet from experiment run 1, 2, and 3, respectively.

C contents (Table 1); the mean concentrations were lower than initial values due to grazing. Food levels were adjusted once (high food), twice (medium food), or three times daily (low food). This food concentration adjustment schedules were tailored according to Campbell et al. (2001). After the acclimation period, approximately 120 individuals were harvested for chemical analyses, and the others (about 70 individuals) were picked out for egg production experiments.

\section{Egg Production Experiments}

The adults were sorted from two food levels at each food quality treatment (Table 1). Five females and two males were transferred into a Plexiglass chamber $(10 \mathrm{~cm}$ in height, $5 \mathrm{~cm}$ diameter with a $250 \mu \mathrm{m}$ mesh $3 \mathrm{~cm}$ above the bottom), which was placed within a $500 \mathrm{~mL}$ bottle filled with a total of $450 \mathrm{~mL}$ culture volume (filtered seawater and food). The $250 \mu \mathrm{m}$ mesh allowed the eggs but not copepod adults to pass through and thus strongly reduced the possibility of egg cannibalism. Eight or ten replicates were set for each treatment except for the lowest food quantity treatment under $\mathrm{N}$ deficiency, in which there were only five replicates. All cultures were maintained under the same conditions as in the acclimation period. After $24 \mathrm{~h}$, the eggs were collected with a $40 \mu \mathrm{m}$ mesh and counted using a Bogorov tray. The $24 \mathrm{~h}$ duration is a suitable incubation period both to avoid the risk of biasing daily estimates and to be representative of the in situ rate (Runge and Roff, 2000).

\section{Analytical Procedure}

Algal cells were counted daily using an improved Neubauer hemacytometer (Glaswarenfabrik Karl Hecht GmbH, Rhön Mountains, Germany) under microscope (Hund, Wetzlar, Germany). For elemental and FA analysis, algae at steady state of semi-continuous cultures were harvested by filtration on precombusted Whatman GF/F filters (Whatman GmbH, Dassel, Germany), while copepods after the acclimation period were first filtered through a $250 \mu \mathrm{m}$ mesh and flushed thoroughly to remove algae, and subsequently collected on pre-combusted Whatman GF/F filters. Samples for elemental analysis were immediately dried and stored in a desiccator, and those for FA analysis were frozen at $-80^{\circ} \mathrm{C}$. Female adults used in egg production experiment were sorted and stored in $-80^{\circ} \mathrm{C}$ for nucleic acid analysis.

The determination of particulate organic $\mathrm{C}$ and $\mathrm{N}$ was carried out after Sharp (1974) by gas chromatography in an organic elemental analyzer (Thermo Flash 2000; Thermo Fisher Scientific, Inc., Schwerte, Germany). Particulate organic $\mathrm{P}$ was analyzed colorimetrically by converting organic phosphorus compounds to orthophosphate (Hansen and Koroleff, 1999).

FAs were measured as fatty acid methyl esters (FAMEs) using a gas chromatograph (Trace GC-Ultra; Thermo Fisher Scientific Inc., Schwerte, Germany). Lipids were extracted with a solvent mixture of chloroform:dichloromethane:methanol (1:1:1 volume ratios). The FAME mixture of 13:0, 15:0, 17:0, 19:0 and 21:0 was added as internal standard, and tricosanoic acid (23:0) added as esterification control. Esterification was done at $50^{\circ} \mathrm{C}$ with a mixture of toluene and methanol which was supplemented with $1 \%$ concentrated sulphuric acid. The extract was dissolved with $\mathrm{n}$-hexane to a final volume of $100 \mu \mathrm{L}$. Sample aliquots $(1 \mu \mathrm{L})$ were given into the GC by splitless injection with hydrogen as the carrier gas. The GC was equipped with a flame ionization detector and a TR-FAME-column (10 m, $0.1 \mathrm{~mm}$ i.d., $0.2 \mu \mathrm{m}$ film). Temperature programme started at $50^{\circ} \mathrm{C}$ for $1 \mathrm{~min}$, increased by $30^{\circ} \mathrm{C} \min ^{-1}$ to $150^{\circ} \mathrm{C}$, then $4^{\circ} \mathrm{C} \mathrm{min}^{-1}$ to $180^{\circ} \mathrm{C}$ and $30^{\circ} \mathrm{C} \mathrm{min}^{-1}$ to $240^{\circ} \mathrm{C}$. Individual FAs were integrated using Chromcard software (Thermo Fisher Scientific, Inc., Schwerte, Germany) and identified with reference to commercially available standards, Supelco 37 component FAME mixture and Supelco Menhaden fish oil. FA data are shown as carbon-normalized

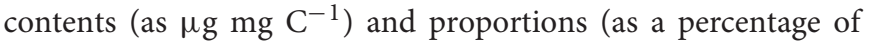
total FAs) in the two species (Supplementary Tables 1, 2). In both species, w3-PUFAs with 18-22 carbon atoms (C18-C22) were mainly represented by $a$-linolenic acid (18:3n-3; ALA), stearidonic acid (SDA; 18:4n-3), EPA and DHA, while C18-C22 w6-PUFAs mainly included 18:2n-6, 18:3n-6 and arachidonic acid (20:4n-6; ARA).

RNA and DNA were analyzed in individual female copepods according to Malzahn et al. (2007). Samples were freeze-dried for at least $16 \mathrm{~h}$ before measurement. RNA and DNA were quantified fluorometrically in a microtiter fluorescence reader (Labsystems, Fluoreskan Ascent) using ethidium bromide as a fluorophore. Total nucleic acids were first measured, and subsequently RNase (Serva, Ribonuclease A) was applied to digest RNA to measure the remaining DNA. Nucleic acid standards were Lambda DNA (Boehringer 745782) and 16S and 23S rRNA (Boehringer 206938). DNA amounts were calculated based on the relationship between RNA and DNA fluorescence (Le Pecq and Paoletti, 1966).

The extended stoichiometric hypothesis permits simultaneous analysis of any number of dietary components for zooplankton production (Anderson and Pond, 2000). Substrate $i$ is limiting if it is in most demand relative to supply as compared to other 
substrates such as $j$, and so the strength of limitation of $i$ relative to $j$, $S_{i: j}$, is:

$$
S_{i: j}=\frac{\phi_{i} \times K_{j}^{*} \times Z_{i: j}}{\phi_{j} \times K_{i}^{*} \times F_{i: j}}
$$

where $F_{i: j}$ and $Z_{i: j}$ are the $i: j$ ratios of components $i$ and $j$ in food and consumer. Parameters $K_{i}^{*}$ and $K_{j}^{*}$ are defined as the maximum GGE for $i$ and $j$, respectively. Only the limiting substrate will be used with a maximum GGE. To take account of possible synthesis of EPA and DHA by the consumer, $\phi_{i}$ and $\phi_{j}$ are introduced as the fraction of demand for constituent $i$ and $j$ which is met directly by dietary intake. When the limitation potential of component $i$ is higher than that of component $j$, the value of $S_{i: j}$ is higher than one and vice versa.

The GGEs for elements are defined as the efficiencies with which elements can be used for zooplankton production (Anderson, 1992; Anderson and Hessen, 1995; Anderson et al., 2004). The relative GGE for each element is governed by the stoichiometric ratio of the elements in the zooplankton versus that in the food (Anderson and Hessen, 1995), and thus can be calculated as: $K_{\mathrm{C}} / K_{\mathrm{N}}=Z_{\mathrm{C}: \mathrm{N}} / F_{\mathrm{C}: \mathrm{N}}$ and $K_{\mathrm{C}} / K_{\mathrm{P}}=Z_{\mathrm{C}: \mathrm{P}} / F_{\mathrm{C}: \mathrm{P}}$.

We show the results for $S_{\mathrm{N} \text { :EPA }}$ and $S_{\mathrm{N}}$ DHA when $A$. tonsa was fed the $\mathrm{N}$-deficient diet, and for $S_{\mathrm{P}: \mathrm{EPA}}$ and $S_{\mathrm{P}: \mathrm{DHA}}$ on the P-deficient diet, respectively. We assume that there is zero synthesis of EPA and DHA by A. tonsa, and thus parameters $\phi_{E P A}$ and $\phi_{D H A}$ are set to 1.0, as suggested by Anderson and Pond (2000). N and P must be of dietary origin, thus $\phi_{N}$ and $\phi_{P}$ are 1.0. The possible upper bound for $K_{\mathrm{N}}{ }^{*}$ and $K_{\mathrm{P}}{ }^{*}$ might be 0.8 (Anderson and Pond, 2000; Anderson et al., 2005; Mayor et al., 2009), thus $K_{\mathrm{N}}{ }^{*}$ and $K_{\mathrm{P}}{ }^{*}$ are each set at 0.8 in this study for A. tonsa on the N- and P-deficient diet, respectively. $K_{\mathrm{EPA}}{ }^{*}$ and $K_{\mathrm{DHA}}{ }^{*}$ are each set at 0.9 (Anderson and Pond, 2000).

\section{Statistical Analysis}

One-way analysis of variance (ANOVA) was conducted to test the effects of experimental run on C:N, C:P and carbon-normalized EPA and DHA contents in Rhodomonas sp., respectively. The same analysis was done for the effects of nutrient treatment. The effects of food quantity on the limiting strengths $S_{\mathrm{N}}$ :EPA and $S_{\mathrm{N}: \mathrm{DHA}}$ in $A$. tonsa fed on the $\mathrm{N}$-deficient diet, and $S_{\mathrm{P}: \mathrm{EPA}}$ and $S_{\text {P:DHA }}$ on the P-deficient diet were also tested by one-way ANOVA. Experimental run showed no significant effects on any response variables in Rhodomonas sp. (Supplementary Table 3). Thus, C:N, C:P and EPA and DHA contents in Rhodomonas sp. are shown as the average values of the three experimental runs for each food quality treatment.

Two-way ANOVA was applied to test the effects of food quantity and quality treatments on C:N, C:P, the contents of EPA and DHA, egg production rates and RNA:DNA in A. tonsa. If there were significant effects, a post hoc test [Tukey's honest significant difference (HSD) test] was applied, and the magnitude of effect was calculated $\left[\omega^{2}=(\right.$ effect sum of squares effect degree of freedom $\times$ error mean square) $/$ (total sum of squares + error mean square)] (Graham and Edwards, 2001; Hughes and Stachowicz, 2009).

Multiple regression was used to analyze the responses of $K_{\mathrm{C}} / K_{\mathrm{X}}$, with the predicting variables of algal C:X ratio, food quantity, (algal C:X ratio) ${ }^{2}$, (food quantity) ${ }^{2}$, and (algal C:X ratio) $\times$ (food quantity), here $\mathrm{X}=\mathrm{N}$ and $\mathrm{P}$, respectively. The same analysis was conducted for the ratios of carbonnormalized $\omega 3$ - (and $\omega 6-$ ) PUFA contents between copepods and algae ( $\omega 3$-PUFA Z/f and $\omega 6$-PUFA Z/f). Dependent and independent variables were $\log _{10}(x)$ transformed to obtain approximate normality and homogeneity of variance in multiple regression analyses.

All statistical analyses were conducted in Statistica 8 (StatSoft [Europe] GmbH, Hamburg, Germany). The significance level was set to $p<0.05$.

\section{RESULTS}

\section{C:N:P Stoichiometry}

The ratios of C:N and C:P in Rhodomonas sp. responded significantly to nutrient treatment changes (ANOVA; bold letters in Table 2). Specifically, we observed the highest C:N ratios under $\mathrm{N}$ deficiency at $20 \%$ of $\mu_{\max }$ (Tukey's HSD test, $p<0.001$; Figure $1 \mathrm{~A}$ and Supplementary Table 4), and the highest C:P ratios under P deficiency at $20 \%$ of $\mu_{\max }$ (Tukey's HSD test, $p \leq 0.022$; Figure 1B).

In $A$. tonsa, the C:N ratios varied significantly with different food quantity and quality treatments (ANOVA; Table 2), showing higher values on the $\mathrm{N}$-deficient diets than those in other two treatments, especially at high food quantity $\left(>900 \mu \mathrm{g} \mathrm{C} \mathrm{L}^{-1}\right)$ (Tukey's HSD test, $p \leq 0.031$; Figure 1C and Supplementary Table 4). The C:P ratios showed non-significant responses to food quantity and quality changes.

\section{Fatty Acids}

In Rhodomonas sp., carbon-normalized contents of EPA responded significantly to different nutrient treatments (ANOVA; Table 2), showing the highest values under $\mathrm{N}$ deficiency (Tukey's HSD test, $p<0.001$; Figure 2A and Supplementary Table 1). However, carbon-normalized contents of DHA showed non-significant changes.

In $A$. tonsa, carbon-normalized EPA contents responded significantly to the changes in food quantity and quality, while DHA varied significantly only with food quality changes (ANOVA; Table 2). The contents of EPA were generally higher at higher food quantities and on nutrient deficient diets (Tukey's HSD test, $p<0.006$; Figure 2C and Supplementary Table 2), while DHA was higher on the P-deficient diets than that on the balanced nutrient diets (Tukey's HSD test, $p=0.008$; Figure 2D).

\section{Gross Growth Efficiency of Elements and the Relative Trophic Transfer Efficiencies of EFAs Versus C}

Multiple regression analyses show that the relative GGE of $K_{\mathrm{C}} / K_{\mathrm{N}}$ responded significantly to all independent variables, while for $K_{\mathrm{C}} / K_{\mathrm{P}}$ regression with only the linear term [algal $\mathrm{C}: \mathrm{P}$ ratio] and the quadratic term [food quantity] ${ }^{2}$ showed the best model fit (bold letters in Table 3). Specifically, $K_{\mathrm{C}} / K_{\mathrm{N}}$ decreased with increasing food quality (algal C:N ratios), but 


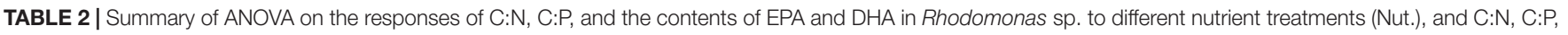
EPA, DHA, the strength of limitation of deficient nutrient relative to essential fatty acids ( $S_{\mathrm{N}: E P A}, S_{N}$ :DHA, $S_{P: E P A}$, and $S_{P}$ :DHA), egg production rates and RNA:DNA in Acartia tonsa to different food quantity (Conc.; $\mu \mathrm{g} \mathrm{C} \mathrm{L}{ }^{-1}$ ) and quality (Nut.).

\begin{tabular}{|c|c|c|c|c|c|c|c|}
\hline Species & Dependent variable & Independent variable & sS & $d f$ & $\boldsymbol{F}$ & $p$ & $\omega^{2}$ \\
\hline \multirow[t]{4}{*}{ Rhodomonas sp. } & $\mathrm{C}: \mathrm{N}\left(\mathrm{mol} \mathrm{mol}{ }^{-1}\right)$ & Nut. & 73.65 & 2 & 126.02 & $<0.001$ & $92 \%$ \\
\hline & $\mathrm{C}: \mathrm{P}\left(\mathrm{mol} \mathrm{mol}{ }^{-1}\right)$ & Nut. & 440.91 & 2 & 38.62 & $<0.001$ & $78 \%$ \\
\hline & 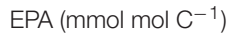 & Nut. & 2.87 & 2 & 23.6 & $<0.001$ & $68 \%$ \\
\hline & $\mathrm{DHA}\left(\mathrm{mmol} \mathrm{mol} \mathrm{C}^{-1}\right)$ & Nut. & 0.010 & 2 & 0.60 & 0.559 & \\
\hline \multirow[t]{22}{*}{ Acartia tonsa } & $\mathrm{C}: \mathrm{N}(\mathrm{mol} \mathrm{mol}-1)$ & Nut. & 0.019 & 2 & 4.83 & 0.022 & $12 \%$ \\
\hline & & Conc. & 0.030 & 5 & 3.15 & 0.034 & $17 \%$ \\
\hline & & Nut. $\times$ Conc. & 0.035 & 10 & 1.81 & 0.134 & \\
\hline & $\mathrm{C}: \mathrm{P}(\mathrm{mol} \mathrm{mol}-1)$ & Nut. & 853.7 & 2 & 0.31 & 0.736 & \\
\hline & & Conc. & 9471.0 & 5 & 1.39 & 0.283 & \\
\hline & & Nut. $\times$ Conc. & 12897.7 & 10 & 0.95 & 0.521 & \\
\hline & EPA (mmol mol $\left.\mathrm{C}^{-1}\right)$ & Nut. & 0.76 & 2 & 10.8 & 0.001 & $23 \%$ \\
\hline & & Conc. & 1.36 & 5 & 7.76 & $<0.001$ & $40 \%$ \\
\hline & & Nut. $\times$ Conc. & 0.22 & 10 & 0.61 & 0.781 & \\
\hline & $\mathrm{DHA}\left(\mathrm{mmol} \mathrm{mol} \mathrm{C}^{-1}\right)$ & Nut. & 3.31 & 2 & 6.11 & 0.011 & $21 \%$ \\
\hline & & Conc. & 3.85 & 5 & 2.84 & 0.051 & \\
\hline & & Nut. $\times$ Conc. & 1.33 & 10 & 0.49 & 0.872 & \\
\hline & $S_{N: E P A}$ & Conc. & 104.0 & 5 & 1.20 & 0.444 & - \\
\hline & $S_{\mathrm{N}: \mathrm{DHA}}$ & Conc. & 2.96 & 5 & 1.65 & 0.325 & - \\
\hline & $S_{P: E P A}$ & Conc. & 237.1 & 5 & 1.24 & 0.396 & - \\
\hline & $S_{P: D H A}$ & Conc. & 7.57 & 5 & 1.04 & 0.472 & - \\
\hline & Egg production & Nut. & 27.84 & 2 & 8.78 & $<0.001$ & $13 \%$ \\
\hline & (eggs female ${ }^{-1} \mathrm{~d}^{-1}$ ) & Conc. & 84.07 & 1 & 53.0 & $<0.001$ & $42 \%$ \\
\hline & & Nut. $\times$ Conc. & 5.30 & 2 & 1.68 & 0.197 & \\
\hline & RNA:DNA & Nut. & 1.23 & 2 & 2.76 & 0.156 & \\
\hline & $\left(\mu g \mu g^{-1}\right)$ & Conc. & 24.6 & 1 & 110.04 & $<0.001$ & $85 \%$ \\
\hline & & Nut. $\times$ Conc. & 1.59 & 2 & 3.55 & 0.110 & \\
\hline
\end{tabular}

The magnitude of effect $\left(\omega^{2}\right)$ is shown only for significant responses. Significant p-values are shown in bold.

this negative response became weaker as food quantity increased (Figure $3 \mathrm{~A}$ ). $K_{\mathrm{C}} / K_{\mathrm{N}}$ increased with increasing food quantity at higher algal $\mathrm{C}: \mathrm{N}$ ratios (N-deficient diets), but showed a unimodal response to food quantity changes at lower $\mathrm{C}: \mathrm{N}$ ratios (balanced nutrient diets). Similarly, $K_{\mathrm{C}} / K_{\mathrm{P}}$ decreased with increasing food quality (algal C:P ratios), but increased with increasing food quantity (Figure 3B).

The strength of limitation of elements relative to EFAs $\left(S_{\mathrm{N}}\right.$ :EPA, $S_{\mathrm{N}: \text { DHA }}, S_{\mathrm{P}: \mathrm{EPA}}$, and $\left.S_{\mathrm{P}: \mathrm{DHA}}\right)$ showed non-significant responses to food quantity changes (ANOVA; Table 2). The values of the four parameters ranged from ca. two to 10 and one to two, respectively, and generally higher at lower food quantity $\left(<900 \mu \mathrm{g} \mathrm{C} \mathrm{L}^{-1}\right)$ (Figure 4).

The values of $\omega 3$-PUFA Z/f responded significantly to food quantity, while $\omega 6$-PUFA Z/f showed significant responses to algal C:N (and C:P) ratios, food quantity and the interactions between algal C:P and food quantity (multiple regression analyses; Table 3). We observed an increased in $\omega 3$-PUFA Z/f as food quantity increased (not shown in figures). Similarly, w6-PUFA Z/f increased with increasing food quantity at higher algal C:N (and C:P) ratios, but decreased at lower algal C:N (and C:P) ratios (Figure 5). Moreover, w6-PUFA $\mathrm{Z} / \mathrm{f}$ generally decreased with increasing algal C:N (and C:P) ratios, but increased with increasing algal $\mathrm{C}: \mathrm{P}$ ratios at high food quantities.

\section{Egg Production Rates and RNA:DNA in Acartia tonsa}

Egg production rates had highly significant responses to food quantity and quality changes (ANOVA; bold letters in Table 2), showing higher values at high food quantities and on the balanced nutrient diet (Figure 6A and Supplementary Table 5). Especially on the balanced nutrient and P-deficient diets, egg production rates were significantly higher at the high food quantity level than those at the low food quantity level (Tukey's HSD test, $p \leq 0.002$ ). At the high food quantity level, egg production rates were higher on the balanced nutrient diet than those on nutrient deficient diets (Tukey's HSD test, $p \leq 0.025$ ).

RNA:DNA in $A$. tonsa varied significantly with food quantity changes (ANOVA; Table 2). At each nutrient treatment, RNA:DNA was significantly higher at the high food quantity level than those at the low food quantity level (Tukey's HSD test, $p \leq 0.049$; Figure 6B and Supplementary Table 5).

\section{DISCUSSION}

Our study demonstrates the variations in C:N:P stoichiometry and FA contents of $A$. tonsa in response to different food quantity and quality treatments, showing significant effects of food quantity and quality on $\mathrm{C}: \mathrm{N}$ ratios and certain essential 


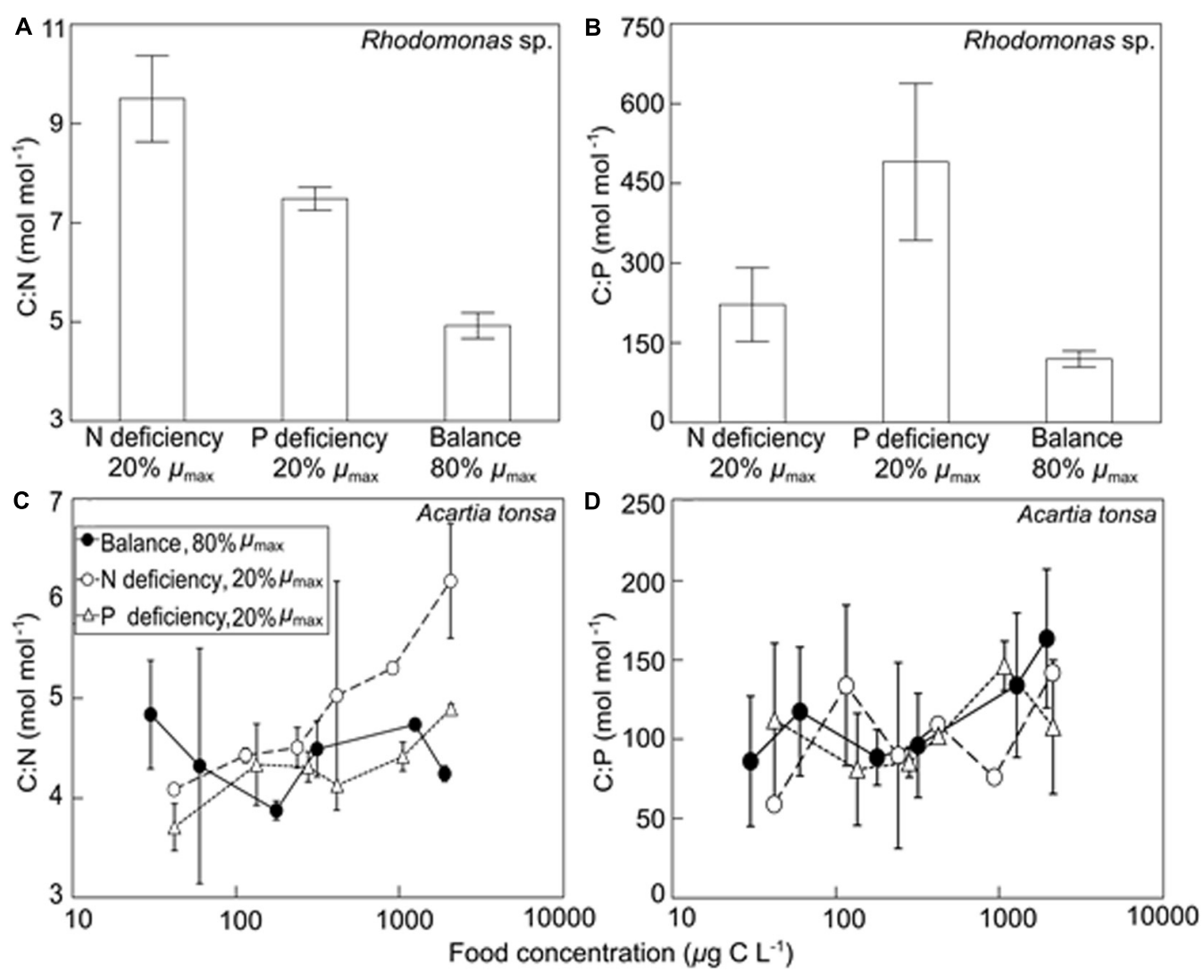

FIGURE 1 | The C:N and C:P ratios (mean \pm SD) in Rhodomonas sp. (A,B) under three nutrient treatments ( $N$ deficiency and $20 \%$ of $\mu$ max, $P$ deficiency and $20 \%$ of $\mu_{\max }$, and the balanced nutrient condition and $80 \%$ of $\left.\mu_{\max }\right)$, and in adult $A$. tonsa (C,D) under different food quantity and quality treatments $[\mathrm{N}$ - and $\mathrm{P}$-deficient and slow growing diets (20\% of $\mu_{\max }$ ) and the balanced nutrient and fast growing diet ( $80 \%$ of $\mu$ max)]. Data presented in Rhodomonas sp. are mean values of the three experimental runs in each nutrient treatment. Note the log scale is used in (C,D).

FA contents but not on C:P ratios. In particular, we observed stronger changes in A. tonsa C:N at higher food concentrations, consistent with previous observations of relaxed rather than strict homeostasis in A. tonsa (Malzahn et al., 2007). The limitation strength of elements and EPA (and DHA) was quantified, and the transfer efficiencies of EFAs and $\mathrm{C}$ were also tested to characterize the mechanisms of homeostatic controls in A. tonsa. We show that the GGE for C and transfer efficiency for EFAs would be reduced on $\mathrm{N}$ - and $\mathrm{P}$-deficient diets, which can explain low egg production rates under nutrient deficient conditions.

\section{Homeostasis of C:N:P Stoichiometry in Acartia tonsa}

Food quality showed significant effects on the C:N ratios, but not C:P ratios in A. tonsa in our study (Table 2 and Figure 1), consistent with early observations for $A$. tonsa feeding on Rhodomonas salina grown in nutrient-replete (f/2), and $\mathrm{N}$ and P-deplete treatments (Malzahn et al., 2010). Different responses between $\mathrm{C}: \mathrm{N}$ and $\mathrm{C}: \mathrm{P}$ ratios in copepods can be explained by the regulation of behavioral and physiological responses on different types of nutrient deficient phytoplankton (Burian et al., 2018). When exposed to N-deficient diets, A. tonsa raised amino acid (AA) retention efficiencies to compensate low dietary AA concentration, while the supply of essential FA became co-limiting and restricted the further increase in AA retention efficiencies (Burian et al., 2018). In our study, DHA concentrations in $A$. tonsa were significantly higher on $\mathrm{N}$-deficient diets, while those in algae showed non-significant changes in response to nutrient concentration changes (Table 2 and Figure 2), suggesting that DHA in the $\mathrm{N}$-deficient diet may have become limiting for A. tonsa. Essential FA depletion may restrict upregulation of $\mathrm{AA}$ retention efficiencies and explain higher C:N ratios in copepods such as Acartia spp., Temora sp., Centropages sp., and Pseudo/Paracalanus spp. feeding on $\mathrm{N}$-deficient diets in this study and previous work (Van Nieuwerburgh et al., 2004; Malzahn et al., 2007; Franco-Santos et al., 2018). The exposure of $A$. tonsa to P-deficient diets caused the increase in maximum ingestion rate (Burian et al., 2018), which may be also the case in our study and led to non-significant changes in C:P ratios in $A$. tonsa.

Food quantity showed significant effects on the C:N ratios in A. tonsa, causing a clear increase in C:N ratios under high food quantity (>900 $\mu \mathrm{g} \mathrm{C} \mathrm{L}^{-1}$ ) (Table 2 and Figure 1). Our results are comparable to previous studies (Malzahn et al., 2007, 2010), which showed significantly higher C:N ratios in A. tonsa feeding 


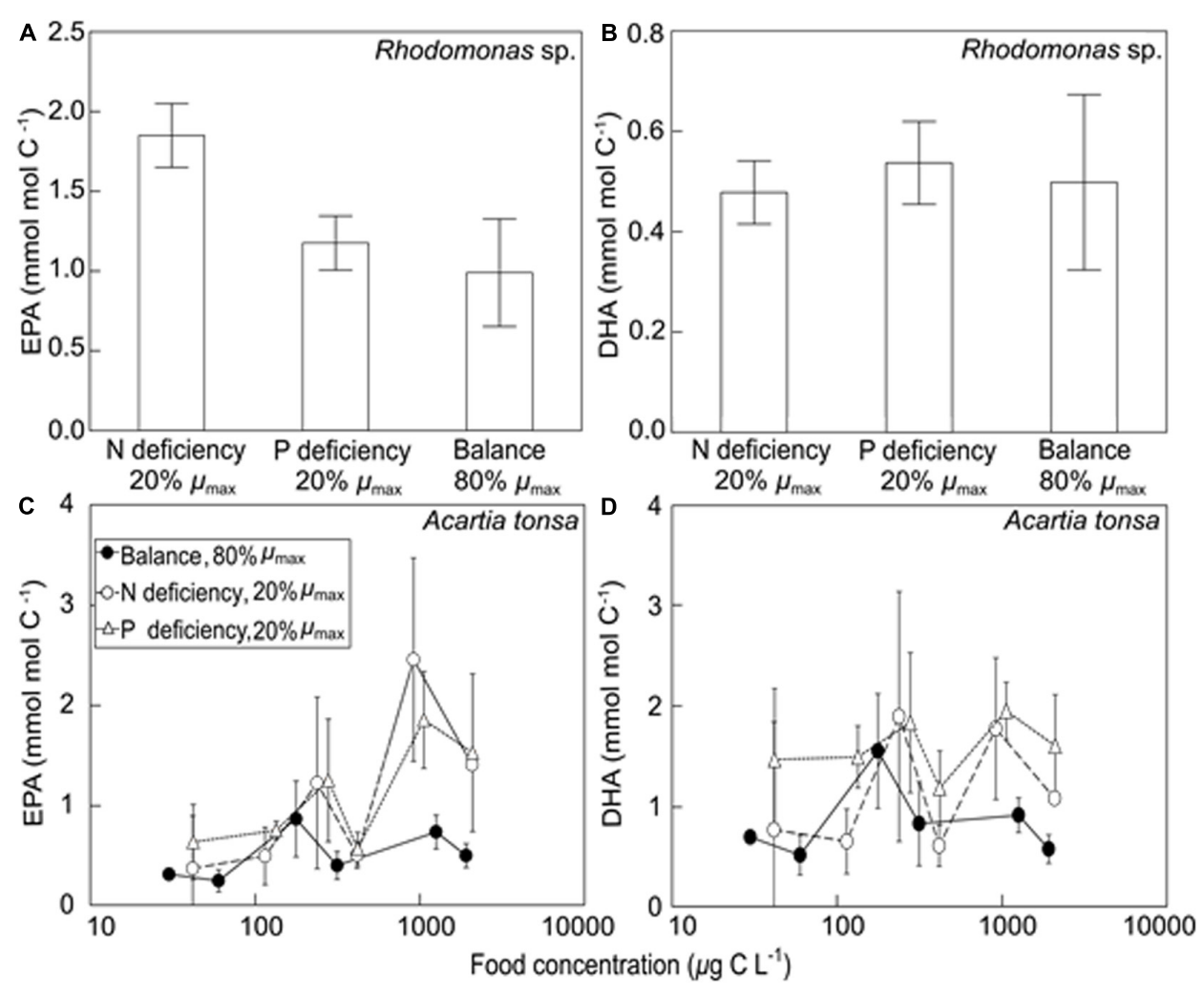

FIGURE 2 | The carbon-normalized contents (mean \pm SD) of EPA (eicosapentaenoic acid; 20:5n-3) and DHA (docosahexaenoic acid; 22:6n-3) in Rhodomonas sp. (A,B) under three nutrient treatments ( $\mathrm{N}$ deficiency and $20 \%$ of $\mu_{\max }, \mathrm{P}$ deficiency and $20 \%$ of $\mu_{\max }$, and the balanced nutrient condition and $80 \%$ of $\mu_{\text {max }}$ ), and in adult $A$. tonsa (C,D) under different food quantity and quality treatments [N- and P-deficient and slow growing diets (20\% of $\mu$ max) and the balanced nutrient and fast growing diet $\left(80 \%\right.$ of $\left.\left.\mu_{\max }\right)\right]$. Data presented in Rhodomonas sp. are mean values of the three experimental runs in each nutrient treatment. Note the log scale is used in (C,D).

TABLE 3 | Results of multiple regression analyses for the relative gross growth efficiency for carbon and nitrogen $\left(K_{C} / K_{N}\right)$, the relative gross growth efficiency for carbon and phosphorus $\left(K_{C} / K_{P}\right)$, the ratio of $\omega 3$-PUFA contents between Acartia tonsa and food ( $\omega 3$-PUFA Z/f), and the ratio of $\omega 6$-PUFA contents between $A$. tonsa and food ( $\omega 6-P U F A$ Z/f).

\begin{tabular}{|c|c|c|c|c|c|c|}
\hline Dependent variable & Independent variable & Parameter estimate \pm SE & $t$ & $p$ & $r^{2}$ (adj.) & $n$ \\
\hline \multirow[t]{5}{*}{$K_{\mathrm{C}} / K_{\mathrm{N}}$} & Algal C:N ratio (C:N) & $-4.74 \pm 1.30$ & -3.68 & 0.001 & 0.86 & 35 \\
\hline & Food concentration $\left(\mathrm{C}_{\mathrm{f}}\right)$ & $-0.53 \pm 0.14$ & -3.70 & $<0.001$ & & \\
\hline & $\mathrm{C}: \mathrm{N}^{2}$ & $1.76 \pm 0.76$ & 2.31 & 0.028 & & \\
\hline & $\mathrm{C}_{\mathrm{f}}^{2}$ & $0.05 \pm 0.03$ & 2.13 & 0.042 & & \\
\hline & $\mathrm{C}: \mathrm{N} \times \mathrm{C}_{\mathrm{f}}$ & $0.38 \pm 0.13$ & 3.07 & 0.005 & & \\
\hline \multirow[t]{2}{*}{$K_{C} / K_{P}$} & Algal C:P ratio $(\mathrm{C}: \mathrm{P})$ & $-1.08 \pm 0.10$ & -10.93 & $<0.001$ & 0.79 & 33 \\
\hline & $\mathrm{C}_{\mathrm{f}}{ }^{2}$ & $0.02 \pm 0.01$ & 2.17 & 0.038 & & \\
\hline \multirow[t]{2}{*}{$\omega 3-P U F A ~ Z / f$} & $\mathrm{C}: \mathrm{N}$ & $0.16 \pm 0.34$ & 0.47 & 0.641 & 0.35 & 34 \\
\hline & $\mathrm{C}_{\mathrm{f}}$ & $0.28 \pm 0.06$ & 4.38 & $<0.001$ & & \\
\hline \multirow[t]{2}{*}{$\omega 3-P U F A ~ Z / f$} & $\mathrm{C}: \mathrm{P}$ & $0.24 \pm 0.14$ & 1.72 & 0.096 & 0.40 & 34 \\
\hline & $\mathrm{C}_{\mathrm{f}}$ & $0.27 \pm 0.06$ & 4.41 & $<0.001$ & & \\
\hline \multirow[t]{3}{*}{$\omega 6-P U F A ~ Z / f$} & $\mathrm{C:N}$ & $-4.55 \pm 1.67$ & -2.73 & 0.011 & 0.29 & 34 \\
\hline & $\mathrm{C}_{\mathrm{f}}$ & $-0.93 \pm 0.52$ & -1.78 & 0.085 & & \\
\hline & $\mathrm{C}: \mathrm{N} \times \mathrm{C}_{f}$ & $1.22 \pm 0.63$ & 1.93 & 0.064 & & \\
\hline \multirow[t]{3}{*}{$\omega 6-P U F A ~ Z / f$} & $C: P$ & $-2.50 \pm 0.71$ & -3.52 & 0.001 & 0.28 & 34 \\
\hline & $\mathrm{C}_{f}$ & $-1.88 \pm 0.66$ & -2.83 & 0.008 & & \\
\hline & $\mathrm{C}: \mathrm{P} \times \mathrm{C}_{f}$ & $0.83 \pm 0.28$ & 2.95 & 0.006 & & \\
\hline
\end{tabular}

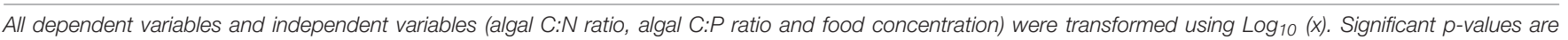
shown in bold; $n$ is the number of observations. 

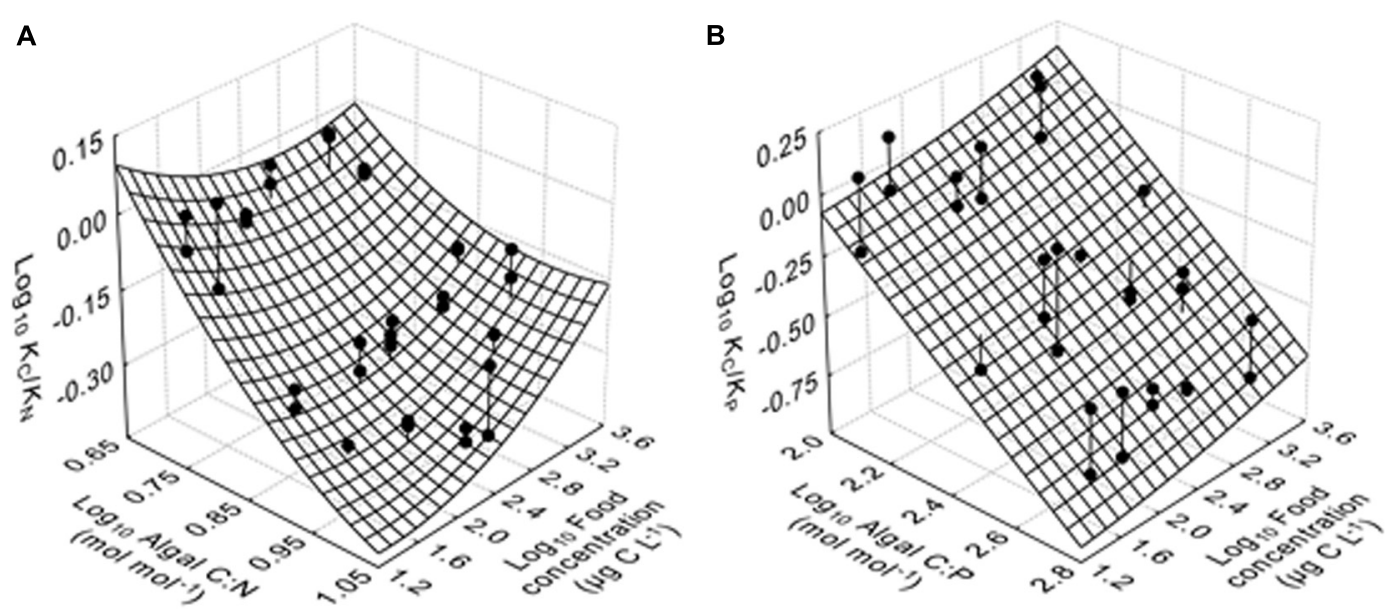

FIGURE 3 | The relative gross growth efficiency (GGE) for carbon and element $X\left(K_{C} / K_{X}\right)$ (here, $X=N$ or $P$ ) as functions of algal C: $X$ ratio and food quantity. (A) The relative GGE for carbon and nitrogen $\left(K_{C} / K_{N}\right)$ as a function of algal C:N ratio and food quantity, fitted to the second-order quadratic equation, and (B) The relative GGE for carbon and phosphorus $\left(K_{\mathrm{C}} / K_{\mathrm{P}}\right)$ as a function of algal C:P ratio and food quantity, fitted to the second-order quadratic equation with only the linear term [algal C:P ratio] and the quadratic term [food quantity] ${ }^{2}$. Data of $K_{C} / K_{X}$, algal C:X and food quantity were transformed using Log ${ }_{10}(X)$. The mesh grid is the 3D surface plot of the model prediction. Observations are represented by ball-and-stick symbols where the stick is the projection of the observation onto the surface plot.

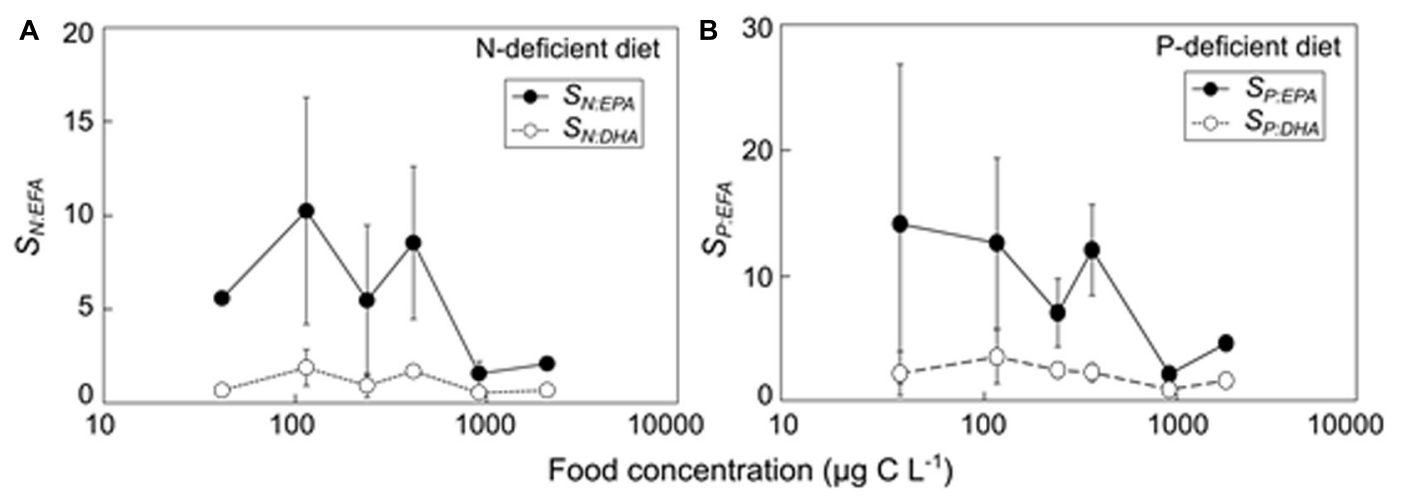

FIGURE 4 | The strength of limitation of deficient nutrient relative to essential fatty acid (EFA: EPA and DHA) on zooplankton production in response to different food quantity: (A) the strength of limitation of $\mathrm{N}$ relative to EPA and DHA ( $S_{\mathrm{N}}$ :EPA and $\left.S_{\mathrm{N}: D H A}\right)$ as a function of food concentrations under $\mathrm{N}$ deficiency, and (B) the strength of limitation of $\mathrm{P}$ relative to EPA and DHA (SP:EPA and $S_{P: D H A}$ ) as a function of food concentrations under P deficiency. Data are shown as mean values \pm SD. Note the log scale is used.

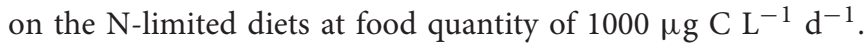
Therefore, the effects of algal C:N ratios on zooplankton C:N ratios are likely more evident at higher food quantity, showing the breakdown of zooplankton stoichiometric homeostasis at higher levels of food quantity (Sterner and Elser, 2002).

To summarize, our results suggest that stoichiometric variability is element dependent, showing that the C:P was more homeostatic than C:N in $A$. tonsa in response to different food quantity and quality treatments. Although the C:N ratios in A. tonsa showed a strong increase on $\mathrm{N}$-deficient diets at high food quantity, they were still lower than those in food. This result suggests that stoichiometry in A. tonsa varies with food $\mathrm{C}: \mathrm{N}: \mathrm{P}$ stoichiometric ratios, while it to some extent dampens the stoichiometric variation in their food (Malzahn et al., 2007). In this regard, it is an important issue to be discussed below, whether stoichiometric homeostasis in A. tonsa is achieved by increasing GGEs for limiting nutrients or by lowering it for C.

\section{Limitation Strength of Elements and EFAs in Acartia tonsa}

The relative GGE, $K_{\mathrm{C}} / K_{\mathrm{N}}$ and $K_{\mathrm{C}} / K_{\mathrm{P}}$, decreased with increasing algal C:N (5-9.5 mol $\mathrm{mol}^{-1}$ ) and C:P ratios (119-440 mol $\mathrm{mol}^{-1}$ ), respectively (Table 3 and Figure 3 ). The response patterns of $K_{\mathrm{C}} / K_{\mathrm{N}}$ are in agreement with previous observations on A. tonsa feeding the diatom Thalassiosira weissflogii (Kiørboe, 1989), and model predictions (Kuijper et al., 2004; Acheampong et al., 2014; Anderson et al., 2017) which showed that $K_{C}$ declined hyperbolically but $K_{\mathrm{N}}$ slightly increased with increasing algal C:N ratios between 5 and $10 \mathrm{~mol} \mathrm{~mol}^{-1}$. Such changes in $K_{\mathrm{C}}$ and $K_{\mathrm{N}}$ 

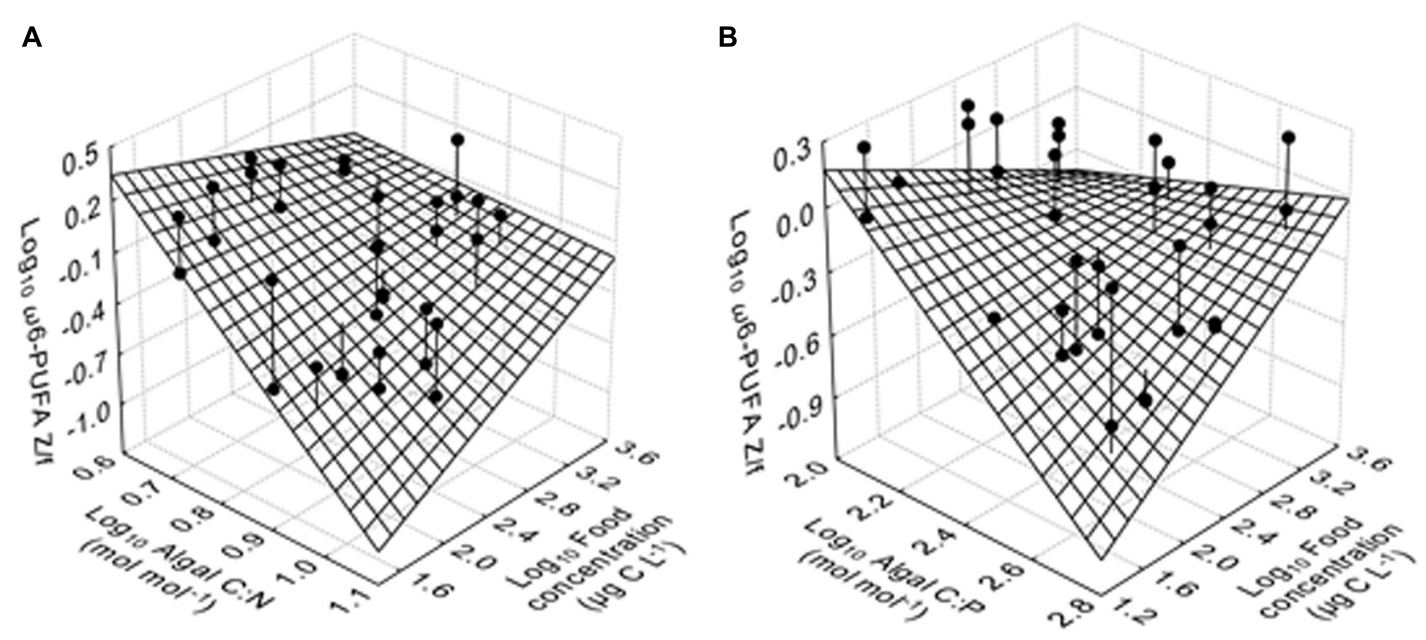

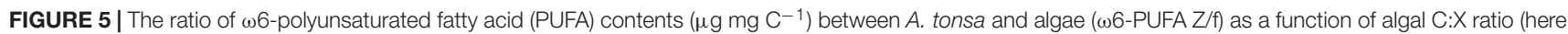
$\mathrm{X}=\mathrm{N}$ or $\mathrm{P}$ ) and food quantity, fitted to the multiple regression model with the linear term algal $\mathrm{C}: \mathrm{X}$ ratios, food quantity and the interactions between the two. (A) $\omega 6$-PUFA Z/f as a function of algal C:N and food quantity, and (B) $\omega 6-P U F A ~ Z / f$ as a function of algal C:P and food quantity. Data of $\omega 6-P U F A ~ Z / f$, algal C:X and food quantity were transformed using $\log _{10}(x)$. The mesh grid is the 3D surface plot of the model prediction. Observations are represented by ball-and-stick symbols where the stick is the projection of the observation onto the surface plot.

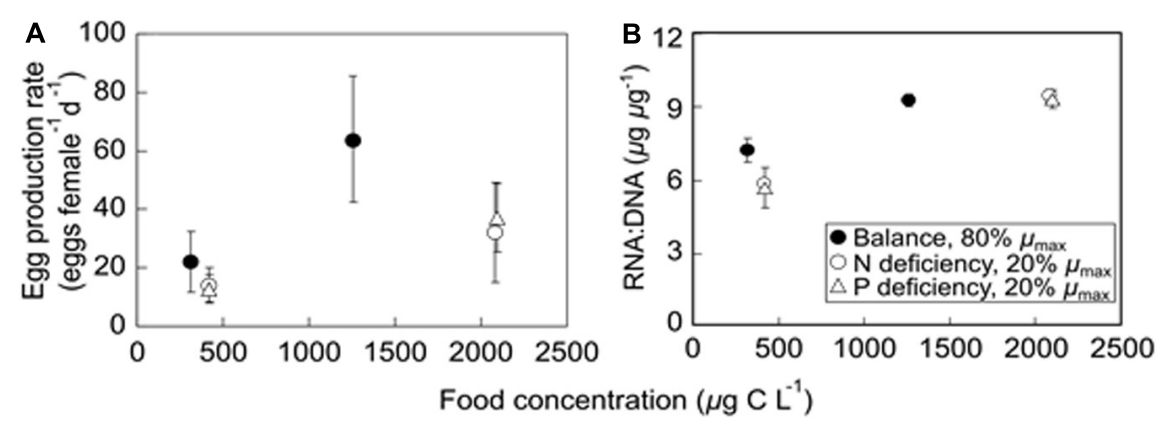

FIGURE 6 | Egg production rate (A) and RNA:DNA (B) (mean \pm SD) in A. tonsa feeding on Rhodomonas sp. under different food quantity and quality treatments [Nand P-deficient and slow growing diets (20\% of $\mu_{\max }$ ) and the balanced nutrient and fast growing diet $\left(80 \%\right.$ of $\left.\left.\mu_{\max }\right)\right]$.

reveal the differential allocations of $\mathrm{C}$ and $\mathrm{N}$ to egg production, indicating a strong decrease in the fraction of $\mathrm{C}$ but a less change in that of $\mathrm{N}$ allocated to egg production with increasing algal C:N ratios in $A$. tonsa (Kuijper et al., 2004).

As food concentration increased, $K_{\mathrm{C}} / K_{\mathrm{N}}$ increased at higher algal $\mathrm{C}: \mathrm{N}$ ratios ( $\mathrm{N}$-deficient diets) and showed a unimodal response at lower algal C:N ratios, while $K_{\mathrm{C}} / K_{\mathrm{P}}$ increased over the entire range of algal C:P ratios in our study (Table 3 and Figure 3). Previous studies have shown variable response patterns of GGE to increasing food concentrations in zooplankton, e.g., positive responses in the copepod Eudiaptomus graciloides (Hamburger and Boētius, 1987), Cyclops vicinus (Santer and van den Bosch, 1994) and Daphnia (Anderson et al., 2005), negative responses in A. tonsa (Kiørboe et al., 1985; Wendt and Thor, 2015), the cladoceran Penilia avirostris (Atienza et al., 2007) and the copepod Oithona davisae (Almeda et al., 2010b), and nonsignificant changes in A. tonsa (Wendt and Thor, 2015). Such variations in zooplankton GGE responses to food concentrations can be explained by differences in nutrient quality of food (e.g., algal C:N and C:P ratios in the present study; Straile, 1997; Bukovinszky et al., 2012), prey species (Wendt and Thor, 2015), development stages of zooplankton (Almeda et al., 2010a), methodological protocols (Straile, 1997), as well as withinpopulation genetic variance in the metabolic rate (Einum et al., 2019). In our study, $K_{\mathrm{C}} / K_{\mathrm{N}}$ and $K_{\mathrm{C}} / K_{\mathrm{P}}$ in $A$. tonsa were overall higher at higher food concentrations, especially when feeding on $\mathrm{N}$ - and P-deficient diets (Figure 3). This result is generally consistent with the predictions of the metabolic stoichiometric model (Anderson et al., 2005). Metabolism has a high C:N ratio (Anderson et al., 2017) and accounts for a lower fraction of intake at high intake (food concentrations), while more substrates are available for egg production (Anderson et al., 2005), indicating higher $K_{\mathrm{C}} / K_{\mathrm{N}}$ at higher intake.

The values of $S_{\mathrm{N}: \mathrm{EPA}}, S_{\mathrm{N}: \mathrm{DHA}}, S_{\mathrm{P}: \mathrm{EPA}}$, and $S_{\mathrm{P}: \mathrm{DHA}}$ were higher than one in our study (Figure 4), suggesting that the limitation potential of $\mathrm{N}$ (and P) was higher than that of EPA and DHA on the N- (and P-) deficient diet. Similarly, Mayor et al. (2009) suggested that limiting potentials for $\mathrm{C}$ and $\mathrm{N}$ were higher than 
those of EPA and DHA for egg production in the copepod Calanus finmarchicus in the north east Atlantic. Furthermore, Mayor et al. (2011) reported variable basal turnover rates and absorption efficiencies for essential PUFAs and N in Calanus spp., and showed that maintenance of essential PUFAs and absorbed $\mathrm{N}$ is a prerequisite for growth, as substantial post-absorptive losses of these substrates are associated with routine tissue maintenance. It can thus be expected that compared to EPA and DHA, the basal turnover rates of $\mathrm{N}$ (and $\mathrm{P}$ ) in $A$. tonsa in the present study may be higher, especially at low food concentrations, causing a relatively high proportion of $\mathrm{N}$ (and $\mathrm{P}$ ) utilized for basal metabolism instead of egg production on the $\mathrm{N}$ - (and P-) deficient diet. This assumption is in correspondence with the results in Malzahn et al. (2007), which suggested that mineral nutrient requirements have to be satisfied first, and FAs can further promote growth of larval herring in experimental tri-trophic food chains with P-deficient phytoplankton. While the primary roles of elemental versus biochemical limitation on zooplankton have long been discussed (Hessen, 1992; Brett, 1993; Müller-Navarra, 1995; Brett et al., 2000; Boersma et al., 2008), our results highlight the necessary to incorporate both elemental and biochemical approaches in the study of food webs (Anderson and Pond, 2000; Sterner and Elser, 2002; Lampert, 2009; Hessen et al., 2013).

Moreover, lower values of $S_{\mathrm{N}: \mathrm{EPA}}, S_{\mathrm{N}: \mathrm{DHA}}, S_{\mathrm{P}: \mathrm{EPA}}$, and $S_{\mathrm{P}: \mathrm{DHA}}$ at higher food concentrations indicate that the strength of limitation of $\mathrm{N}(\mathrm{P})$ relative to EFAs was reduced as food concentrations increased (Figure 4). It is well-known that ingestion and assimilation of zooplankton such as Daphnia increase with increasing food concentrations, and at threshold food concentrations the metabolic expenditure is balanced with net food intake and production equals zero (Lampert, 1977; Lampert and Sommer, 2007). According to the metabolic stoichiometric model, the proportions of $\mathrm{C}, \mathrm{N}$ and $\mathrm{P}$ used for growth increase at high intake (Anderson et al., 2005). This positive relationship between growth efficiencies and intake can be attributed to the diminishing relative cost of maintenance (Anderson et al., 2005), which may explain the reduced limitation strength of $\mathrm{N}$ (and $\mathrm{P}$ ) relative to EFAs at high food concentrations in A. tonsa in this study.

Altogether, we suggest that homeostatic stoichiometry in A. tonsa may be maintained by the reduced $K_{\mathrm{C}}$ and increased $K_{\mathrm{N}}$ (and $K_{\mathrm{P}}$ ) when feeding on $\mathrm{N}$ - (and $\mathrm{P}-$ ) deficient diets, which underlies differential mechanisms of $\mathrm{C}$ and $\mathrm{N}$ (and P) in controlling zooplankton production, and indicates that $\mathrm{N}$ and $\mathrm{P}$ are retained more efficiently than $\mathrm{C}$ in zooplankton. Significant interactions between food quantity and quality on $K_{\mathrm{C}} / K_{\mathrm{N}}$ indicate that differences in dietary C:N ratios can result in variable responses of GGE to food concentration changes in A. tonsa. Our results indicate a higher limitation potential of $\mathrm{N}$ (and P) than that of EPA and DHA for A. tonsa feeding on the N(and P-) deficient diet, while the limitation potential of $\mathrm{N}$ (and P) was reduced as food concentration increased.

\section{Egg Production Rates in Acartia tonsa}

Our results show that egg production rates in $A$. tonsa responded significantly to the changes of food quantity and quality, showing overall higher values on the balanced nutrient diets at the high food quantity level, and the lower ones on nutrient deficiency diets at the low food quantity (Table 2 and Figure 6). It is well-established that egg production rate is higher when the food is obtained from nutrient-enriched or other optimized environments (Kleppel et al., 1998). Our results are generally in agreement with early observations which showed higher egg production rates in $A$. tonsa at higher food quantities (Jónasdóttir, 1994; Gusmão and McKinnon, 2009; Acheampong et al., 2011; Wendt and Thor, 2015), or at higher food qualities (lower food C:N ratios) (Kiørboe, 1989). In contrast, nonsignificant changes or a decrease in egg production rates were also found with increasing dietary $\mathrm{C}: \mathrm{N}$ in $A$. tonsa (Jónasdóttir, 1994; Augustin and Boersma, 2006). For example, at similar food quantity and elemental food quality using the same algal species with our study, Augustin and Boersma (2006) reported that egg production rates in $A$. tonsa were about 10 eggs female $\mathrm{d}^{-1} \mathrm{~d}^{-1}$ on $\mathrm{N}$-sufficient diets, which was higher than that on $\mathrm{N}$-depleted diets (about 4 eggs female ${ }^{-1} \mathrm{~d}^{-1}$ ) at $15^{\circ} \mathrm{C}$ and a salinity of $32-33$. These values of egg production rates were lower than that in our study (14 and 22 eggs female ${ }^{-1}$ $\mathrm{d}^{-1}$ on $\mathrm{N}$ deficient and balanced nutrient diets, respectively; Supplementary Table 5), where A. tonsa was cultured at $18^{\circ} \mathrm{C}$ and a salinity of 18 . It has been observed that egg production rates in copepods vary strongly with the changes in temperature (Koski and Kuosa, 1999; Holste and Peck, 2006; Neila et al., 2012) and salinity (Augustin, 2006; Peck and Holste, 2006; Devreker et al., 2009); therefore, differences in temperature and salinity may potentially explain the differential results in our study and Augustin and Boersma (2006). Future studies should consider the interactions between environmental factors and food quality to better understand the responses of copepod production to the changing environments.

Biochemical limitation may be one of reasonable options to explain the low egg production rates when feeding on nutrient deficient diets in our study, because nutrient deficiency of phytoplankton can influence its biochemical contents such as FAs (Bi et al., 2014, 2017). Also, it has been observed that higher EFA contents have positive effects on egg production rates in A. tonsa (Amin et al., 2011; Rossoll et al., 2012). Thus, nutrient deficiency might be the ultimate cause and FA-limitation the proximate cause of lowered egg production rate. This, however, is not the case in our study, as PUFA contents in Rhodomonas sp. were even higher under $\mathrm{N}$ - and P-deficient conditions (Supplementary Table 1). This result is in agreement with stoichiometric analysis above which showed that $\mathrm{N}$ (and $\mathrm{P}$ ) had a limitation potential higher than that of EFAs for A. tonsa on the N- (and P-) deficient diet.

Furthermore, we observed that the ratios of $\omega 3$ - (and $\omega 6-$ ) PUFA contents between $A$. tonsa and food (PUFA Z/f) varied with food concentrations and nutrient treatments (Table 3 and Figure 5). For example, we observed significant negative responses of $\omega 6$-PUFA Z/f to increasing food C:N and C:P ratios, suggesting that the relative transfer efficiency of $\omega 6$-PUFA to carbon may reduce with increasing food C:N and C:P. Because $K_{\mathrm{C}}$ in $A$. tonsa may decrease on $\mathrm{N}$ - and P-deficient diets, it is reasonable to assume that transfer efficiency of w6-PUFAs may also decrease, and even to a larger extent compared to 
carbon, in such food conditions. Co-limitation of food quantity (in terms of carbon) and quality (in terms of N, P and FAs) has been observed to influence the egg production of the North Sea copepod Pseudocalanus elongatus (Koski et al., 2010). Also, our results suggest that a lowered GGE for C might also lower the GGE of EFAs, which would mean that elements and EFAs are interactive-essential and not Liebig-type essential resources for the egg production in A. tonsa.

\section{CONCLUSION}

Our study provides new insight into trophic interactions between marine phytoplankton and copepods, with emphasis on trophic transfer of elements and EFAs, as well as the regulations of zooplankton reproduction. Overall, C:N ratios in A. tonsa changed significantly; however, the copepod C:P was more homeostatic than $\mathrm{C}: \mathrm{N}$ and independent from algal C:P, but still showed some degree of variability. We also showed that C:N:P in A. tonsa was more homeostatic than its diets. Homeostasis in A. tonsa can be maintained via regulating GGEs for elements, with a reduced GGE for $\mathrm{C}$ and enhanced GGEs for $\mathrm{N}$ (and $\mathrm{P}$ ) on $\mathrm{N}$ - (and P-) deficient diets assumed based on our results. Moreover, we first conducted experimental and mathematical analysis on elemental and FA limitation of food quality, showing a higher limitation potential of $\mathrm{N}$ (and P) relative to EPA and DHA for $A$. tonsa egg production when feeding on the $\mathrm{N}$ (and P-) deficient diet. Egg production rates in A. tonsa were considerably reduced as the costs associated with homeostatic regulations on nutrient deficient diets. Along with the lowered GGE for C, reduced transfer efficiency of $\omega 3$ - and $\omega 6$-PUFAs may also contribute to low egg production rates on nutrient deficient diets. Therefore, $\mathrm{N}$ and $\mathrm{P}$ deficiency in the environments can alter phytoplankton chemical composition, reduce trophic transfer efficiencies of $\mathrm{C}$ and EFAs from phytoplankton to zooplankton, decrease zooplankton production, and eventually change the structure and functions of marine food webs.

\section{DATA AVAILABILITY STATEMENT}

All datasets generated for this study are included in the article/Supplementary Material.

\section{REFERENCES}

Acheampong, E., Campbell, R. W., Diekmann, A. B. S., and St John, M. A. (2011). Food availability effects on reproductive strategy: the case of Acartia tonsa (Copepoda: Calanoida). Mar. Ecol. Prog. Ser. 428, 151-159. doi: 10.3354/ meps09061

Acheampong, E., Hense, I., and St John, M. A. (2014). A model for the description of feeding regulation by mesozooplankton under different conditions of temperature and prey nutritional status. Ecol. Model. 272, 84-97. doi: 10.1016/ j.ecolmode1.2013.09.009

Almeda, R., Augustin, C. B., Alcaraz, M., Calbet, A., and Saiz, E. (2010a). Feeding rates and gross growth efficiencies of larval developmental stages of Oithona davisae (Copepoda, Cyclopoida). J. Exp. Mar. Biol. Ecol. 387, 24-35. doi: 10. 1016/j.jembe.2010.03.002

\section{AUTHOR CONTRIBUTIONS}

$\mathrm{RB}$ and US planning of experiments and writing. RB conduction of experiments, sample analysis, data analysis and figures.

\section{FUNDING}

This study was supported by the National Natural Science Foundation of China (Grant Nos. 41876118 and 41630966), the State Sponsored Graduate Scholarship Program, China Scholarship Council (CSC), and the Youth Talent Support Program of the Laboratory for Marine Ecology and Environmental Science, Pilot National Laboratory for Marine Science and Technology (Qingdao) (Grant No. LMEES-YTSP2018-02-01).

\section{ACKNOWLEDGMENTS}

We wish to thank Thomas Hansen, Cordula Meyer, and Bente Gardeler for technical assistance, and Alexander Raschke, Tanya Schchipkova, Hui Zhang, and Ashley Cipriano for their help during the experiments. We thank Martina Wichmann, Berenike Diekmann and Myron Peck for providing Acartia tonsa eggs, Dennis Rossoll for introducing the protocol for assessing copepod egg production, and Dennis Brennecke for helping with FA analysis. We are also grateful for comments from Stefanie Ismar, Meixun Zhao and three reviewers that greatly improved this manuscript. This work is modified after the Ph.D. thesis of Bi (2013). This is MCTL contribution 217.

\section{SUPPLEMENTARY MATERIAL}

The Supplementary Material for this article can be found online at: https://www.frontiersin.org/articles/10.3389/fmars. 2020.00274/full\#supplementary-material

Almeda, R., Calbet, A., Alcaraz, M., Yebra, L., and Saiz, E. (2010b). Effects of temperature and food concentration on the survival, development and growth rates of naupliar stages of Oithona davisae (Copepoda, Cyclopoida). Mar. Ecol. Prog. Ser. 410, 97-109. doi: 10.3354/meps08625

Amarasinghe, P. B., Boersma, M., and Vijverberg, J. (1997). The effect of temperature, and food quantity and quality on the growth and development rates in laboratory-cultured copepods and cladocerans from a Sri Lankan reservoir. Hydrobiologia 350, 131-144. doi: 10.1023/a:100308781 5861

Ambler, J. W. (1986). Effect of food quantity and quality on egg production of acartia tonsa dana from East Lagoon, Galveston, Texas. Estuar. Coast. Shelf Sci. 23, 183-196. doi: 10.1016/0272-7714(86)90053-3

Amin, R. M., Koski, M., Bamstedt, U., and Vidoudez, C. (2011). Strain-related physiological and behavioral effects of Skeletonema marinoi on three common 
planktonic copepods. Mar. Biol. 158, 1965-1980. doi: 10.1007/s00227-0111706-7

Anderson, T. R. (1992). Modelling the influence of food C:N ratio, and respiration on growth and nitrogen excretion in marine zooplankton and bacteria. J. Plankton Res. 14, 1645-1671. doi: 10.1093/plankt/14.12.1645

Anderson, T. R., Boersma, M., and Raubenheimer, D. (2004). Stoichiometry: linking elements to biochemicals. Ecology 85, 1193-1202. doi: 10.1890/02-0252

Anderson, T. R., and Hessen, D. O. (1995). Carbon or nitrogen limitation in marine copepods? J. Plankton Res. 17, 317-331. doi: 10.1093/plankt/17.2.317

Anderson, T. R., Hessen, D. O., Boersma, M., Urabe, J., and Mayor, D. J. (2017). Will invertebrates require increasingly carbon-rich food in a warming world? Am. Nat. 190, 725-742. doi: 10.1086/694122

Anderson, T. R., Hessen, D. O., Elser, J. J., and Urabe, J. (2005). Metabolic stoichiometry and the fate of excess carbon and nutrients in consumers. Am. Nat. 165, 1-15. doi: 10.1086/426598

Anderson, T. R., and Pond, D. W. (2000). Stoichiometric theory extended to micronutrients: Comparison of the roles of essential fatty acids, carbon, and nitrogen in the nutrition of marine copepods. Limnol. Oceanogr. 45, 1162-1167. doi: 10.4319/lo.2000.45.5.1162

Arts, M. T., Ackman, R. G., and Holub, B. J. (2001). Essential fatty acids in aquatic ecosystems: a crucial link between diet and human health and evolution. Can. J. Fish. Aquat. Sci. 58, 122-137. doi: 10.1139/f00-224

Atienza, D., Calbet, A., Saiz, E., and Lopes, R. M. (2007). Ecological success of the cladoceran Penilia avirostris in the marine environment: feeding performance, gross growth efficiencies and life history. Mar. Biol. 151, 1385-1396. doi: 10. 1007/s00227-006-0578-8

Augustin, C. B. (2006). Food and Climate Effects On Copepod Reproduction In The North and Baltic Seas. Ph. D. thesis, Christian-Albrechts-Universität zu Kiel, Kiel.

Augustin, C. B., and Boersma, M. (2006). Effects of nitrogen stressed algae on different Acartia species. J. Plankton Res. 28, 429-436. doi: 10.1093/plankt/ fbil31

Becker, C., and Boersma, M. (2005). Differential effects of phosphorus and fatty acids on Daphnia magna growth and reproduction. Limnol. Oceanogr. 50, 388-397. doi: $10.2307 / 3597910$

Bi, R. (2013). Chemical Composition Of Phytoplankton As The Determinant Of Food Quality. Ph. D. thesis, Christian-Albrechts-Universität zu Kiel, Kiel.

Bi, R., Arndt, C., and Sommer, U. (2012). Stoichiometric responses of phytoplankton species to the interactive effect of nutrient supply ratios and growth rates. J. Phycol. 48, 539-549. doi: 10.1111/j.1529-8817.2012.01163.x

Bi, R., Arndt, C., and Sommer, U. (2014). Linking elements to biochemicals: effects of nutrient supply ratios and growth rates on fatty acid composition of phytoplankton species. J. Phycol. 50, 117-130. doi: 10.1111/jpy.12140

Bi, R., Ismar, S. M. H., Sommer, U., and Zhao, M. (2017). Environmental dependence of the correlations between stoichiometric and fatty acid-based indicators of phytoplankton nutritional quality. Limnol. Oceanogr. 62, 334-347. doi: $10.1002 /$ lno.10429

Bi, R., Ismar, S. M. H., Sommer, U., and Zhao, M. (2018). Simultaneous shifts in stoichiometric and fatty acid composition of Emiliania huxleyi in response to environmental changes. Biogeosciences 15, 1029-1045. doi: 10.5194/bg-151029-2018

Boersma, M. (2000). The nutritional quality of P-limited algae for Daphnia. Limnol. Oceanogr. 45, 1157-1161. doi: 10.4319/lo.2000.45.5.1157

Boersma, M., Aberle, N., Hantzsche, F. M., Schoo, K. L., Wiltshire, K. H., and Malzahn, A. M. (2008). Nutritional limitation travels up the food chain. Internat. Rev. Hydrobiol. 93, 479-488. doi: 10.1002/iroh.200811066

Boersma, M., and Kreutzer, C. (2002). Life at the edge: is food quality really of minor importance at low quantities?. Ecology 83, 2552-2561. doi: 10.1890/ 0012-9658(2002)083\%5B2552:lateif\%5D2.0.co;2

Boyce, D. G., Lewis, M. R., and Worm, B. (2010). Global phytoplankton decline over the past century. Nature 466, 591-596. doi: 10.1038/nature09268

Brett, M., and Müller-Navarra, D. C. (1997). The role of highly unsaturated fatty acids in aquatic foodweb processes. Freshw. Biol. 38, 483-499. doi: 10.1046/j. 1365-2427.1997.00220.x

Brett, M. T. (1993). Comment on Possibility of N or P limitation for planktonic cladocerans: an experimental test (Urabe and Watanabe) and Nutrient element limitation of zooplankton production (Hessen). Limnol. Oceanogr. 38, 13331337. doi: $10.4319 /$ lo.1993.38.6.1333
Brett, M. T., Muller-Navarra, D. C., and Park, S. K. (2000). Empirical analysis of the effect of phosphorus limitation on algal food quality for freshwater zooplankton. Limnol. Oceanogr. 45, 1564-1575. doi: 10.4319/lo.2000.45.7.1564

Bukovinszky, T., Verschoor, A. M., Helmsing, N. R., Bezemer, T. M., Bakker, E. S., Vos, M., et al. (2012). The good, the bad and the plenty: Interactive effects of food quality and quantity on the growth of different Daphnia species. PLoS One 7:42966. doi: 10.1371/journal.pone.0042966

Burian, A., Grosse, J., Winder, M., and Boschker, H. T. S. (2018). Nutrient deficiencies and the restriction of compensatory mechanisms in copepods. Funct. Ecol. 32, 636-647. doi: 10.1111/1365-2435.13016

Campbell, R. G., Melissa, M. W., Gregory, J. T., Carla, A. B., and Edward, G. D. (2001). Growth and development rates of the copepod Calanus finmarchicus reared in the laboratory. Mar. Ecol. Prog. Ser. 221, 161-183. doi: 10.3354/ meps221161

Capuzzo, E., Lynam, C. P., Barry, J., Stephens, D., Forster, R. M., Greenwood, N., et al. (2018). A decline in primary production in the North Sea over 25 years, associated with reductions in zooplankton abundance and fish stock recruitment. Glob. Change Biol. 24, E352-E364. doi: 10.1111/gcb.13916

Dagg, M. (1977). Some effects of patchy food environments on copepods. Limnol. Oceanogr. 22, 99-107. doi: 10.4319/lo.1977.22.1.0099

Devreker, D., Souissi, S., Winkler, G., Forget-Leray, J., and Leboulenger, F. (2009). Effects of salinity, temperature and individual variability on the reproduction of Eurytemora affinis (Copepoda; Calanoida) from the seine estuary: a laboratory study. J. Exp. Mar. Biol. Ecol. 368, 113-123. doi: 10.1016/j.jembe.2008.10.015

Diez, B., Van Nieuwerburgh, L., and Snoeijs, P. (2013). Water nutrient stoichiometry modifies the nutritional quality of phytoplankton and somatic growth of crustacean mesozooplankton. Mar. Ecol. Prog. Ser. 489, 93-105. doi: 10.3354/meps 10438

Downing, J. A. (1997). Marine nitrogen: phosphorus stoichiometry and the global N:P cycle. Biogeochemistry 37, 237-252. doi: 10.1023/a:1005712322036

Drillet, G., Iversen, M. H., Sørensen, T. F., Ramløv, H., Lund, T., and Hansen, B. W. (2006). Effect of cold storage upon eggs of a calanoid copepod, Acartia tonsa (Dana) and their offspring. Aquaculture 254, 714-729. doi: 10.1016/j. aquaculture.2005.11.018

Edwards, M., and Richardson, A. J. (2004). Impact of climate change on marine pelagic phenology and trophic mismatch. Nature 430, 881-884. doi: 10.1038/ nature 02808

Einum, S., Fossen, E. I. F., Parry, V., and Pelabon, C. (2019). Genetic variation in metabolic rate and correlations with other energy budget components and life history in Daphnia magna. Evol. Biol. 46, 170-178. doi: 10.1007/s11692-01909473-x

Franco-Santos, R. M., Auel, H., Boersma, M., De Troch, M., Meunier, C. L., and Niehoff, B. (2018). Bioenergetics of the copepod Temora longicornis under different nutrient regimes. J. Plankton Res. 40, 420-435. doi: 10.1093/plankt/ fby016

Galbraith, E. D., and Martiny, A. C. (2015). A simple nutrient-dependence mechanism for predicting the stoichiometry of marine ecosystems. Proc. Natl. Acad. Sci. U.S.A. 112, 8199-8204. doi: 10.1073/pnas.1423917112

Gladyshev, M., Sushchik, N., Anishchenko, O., Makhutova, O., Kolmakov, V., Kalachova, G., et al. (2011). Efficiency of transfer of essential polyunsaturated fatty acids versus organic carbon from producers to consumers in a eutrophic reservoir. Oecologia 165, 521-531. doi: 10.1007/s00442-010-1843-6

Gorokhova, E. (2003). Relationships between nucleic acid levels and egg production rates in Acartia bifilosa: implications for growth assessment of copepods in situ. Mar. Ecol. Prog. Ser. 262, 163-172. doi: 10.3354/meps262163

Graham, M. H., and Edwards, M. S. (2001). Statistical significance versus fit: estimating the importance of individual factors in ecological analysis of variance. Oikos 93, 505-513. doi: 10.1034/j.1600-0706.2001.930317.x

Guillard, R. R. L. (1975). "Culture of phytoplankton for feeding marine invertebrates," in Culture of Marine Invertebrate Animals, eds W. L. Smith, and M. H. Chanley, (Boston, MA: Springer), 29-60. doi: 10.1007/978-1-4615-87 14-9_3

Gusmão, L. F. M., and McKinnon, A. D. (2009). The effect of food type and quantity on egg production and nucleic acid content of Acartia sinjiensis. Aquaculture 296, 71-80. doi: 10.1016/j.aquaculture.2009.08.015

Gusmão, L. F. M., and McKinnon, A. D. (2011). Nucleic acid indices of egg production in the tropical copepod Acartia sinjiensis. J. Exp. Mar. Biol. Ecol. 396, 122-137. doi: 10.1016/j.jembe.2010.10.008 
Hamburger, K., and Boētius, F. (1987). Ontogeny of growth, respiration and feeding rate of the freshwater calanoid copepod Eudiaptomus graciloides. J. Plankton Res. 9, 589-606. doi: 10.1093/plankt/9.4.589

Hansen, H. P., and Koroleff, F. (1999). "Determination of nutrients," in Methods of Seawater Analysis, 3rd Edn, eds K. Grasshoff, K. Kremling, and M. Ehrhardt, (Weinheim: Wiley-VCH), 159-228. doi: 10.1002/9783527613984.ch10

Harris, R., Wiebe, P., Lenz, J., Skjoldal, H. R., and Huntley, M. (2000). Zooplankton Methodology Manual. London: Academic Press.

Haury, L. R., and Yamazaki, H. (1995). The dichotomy of scales in the perception and aggregation behavior of zooplankton. J. Plankton Res. 17, 191-197. doi: 10.1093/plankt/17.1.191

Herstoff, E. M., Baines, S. B., Boersma, M., and Meunier, C. L. (2019). Does prey elemental stoichiometry influence copepod movement over ontogeny? Limnol. Oceanogr. 9999, 1-11. doi: 10.1002/lno.11198

Hessen, D. O. (1992). Nutrient element limitation of zooplankton production. Am. Nat. 140, 799-814. doi: 10.1086/285441

Hessen, D. O. (2008). Efficiency, energy and stoichiometry in pelagic food webs; reciprocal roles of food quality and food quantity. Freshw. Rev. 1, 43-57. doi: $10.1608 /$ frj-1.1.3

Hessen, D. O., Elser, J. J., Sterner, R. W., and Urabe, J. (2013). Ecological stoichiometry: An elementary approach using basic principles. Limnol. Oceanogr 58, 2219-2236. doi: 10.4319/lo.2013.58.6.2219

Holste, L., and Peck, M. (2006). The effects of temperature and salinity on egg production and hatching success of Baltic Acartia tonsa (Copepoda: Calanoida): a laboratory investigation. Mar. Biol. 148, 1061-1070. doi: 10.1007/s00227-005$0132-0$

Hughes, A. R., and Stachowicz, J. J. (2009). Ecological impacts of genotypic diversity in the clonal seagrass Zostera marina. Ecology 90, 1412-1419. doi: 10.1890/07-2030.1

Ilić, M., Werner, C., and Fink, P. (2019). Equal relevance of omega-3 and omega-6 polyunsaturated fatty acids for the fitness of Daphnia spp. Limnol. Oceanogr. 64, 2512-2525. doi: 10.1002/lno.11201

Ismar, S. M. H., Hansen, T., and Sommer, U. (2008). Effect of food concentration and type of diet on Acartia survival and naupliar development. Mar. Biol. 154, 335-343. doi: 10.1007/s00227-008-0928-9

Jónasdóttir, S. H. (1994). Effects of food quality on the reproductive success of Acartia tonsa and Acartia hudsonica: laboratory observations. Mar. Biol. 121, 67-81. doi: 10.1007/BF00349475

Jónasdóttir, S. H., Visser, A. W., and Jespersen, C. (2009). Assessing the role of food quality in the production and hatching of Temora longicornis eggs. Mar. Ecol. Prog. Ser. 382, 139-150. doi: 10.3354/meps07985

Kainz, M., Arts, M. T., and Mazumder, A. (2004). Essential fatty acids in the planktonic food web and their ecological role for higher trophic levels. Limnol. Oceanogr. 49, 1784-1793. doi: 10.4319/lo.2004.49.5.1784

Kiørboe, T. (1989). Phytoplankton growth rate and nitrogen content: implications for feeding and fecundity in a herbivorous copepod. Mar. Ecol. Prog. Ser. 55, 229-234. doi: 10.3354/meps055229

Kiørboe, T., Møhlenberg, F., and Hamburger, K. (1985). Bioenergetics of the planktonic copepod Acartia tonsa: relation between feeding, egg production and respiration, and composition of specific dynamic action. Mar. Ecol. Prog. Ser. 26, 85-97. doi: 10.3354/meps026085

Kleppel, G. S., Burkart, C., and Tomas, C. (1998). Egg production of the copepod Acartia tonsa in Florida Bay during summer. 1. The roles of food environment and diet. Estuaries 21, 328-339. doi: 10.2307/1352479

Koski, M., Dutz, J., Klein Breteler, W., Rampen, S., and Noordeloos, A. (2010). Seasonal changes in food quantity and quality of the common North Sea copepods Temora longicornis and Pseudocalanus elongatus: a bioassay approach. Mar. Ecol. Prog. Ser. 399, 141-155. doi: 10.3354/meps08357

Koski, M., and Kuosa, H. (1999). The effect of temperature, food concentration and female size on the egg production of the planktonic copepod Acartia bifilosa. J. Plankton Res. 21, 1779-1790. doi: 10.1093/plankt/21.9.1779

Kuijper, L. D. J., Anderson, T. R., and Kooijman, S. A. L. M. (2004). C and N gross growth efficiencies of copepod egg production studied using a Dynamic Energy Budget model. J. Plankton Res. 26, 213-226. doi: 10.1093/plankt/fbh020

Lampert, W. (1977). Studies on the carbon balance of Daphnia pulex as related to environmental conditions. IV. Determination of the 'threshold' concentration as a factor controlling the abundance of zooplankton species. Arch. Hydrobiol. $48,361-368$.
Lampert, W. (2009). "Foreword," in Lipids in Aquatic Ecosystems, eds M. T. Arts, M. T. Brett, and M. J. Kainz, (Heidelberg: Springer), 5-6. doi: 10.1111/j.16512227.2006.tb02370.x

Lampert, W., and Sommer, U. (2007). Limnoecology: The Ecology Of Lakes And Streams. Oxford: Oxford University Press.

Le Pecq, J.-B., and Paoletti, C. (1966). A new fluorometric method for RNA and DNA determination. Anal. Biochem. 17, 100-107. doi: 10.1016/0003-2697(66) 90012-1

Lewandowska, A. M., Boyce, D. G., Hofmann, M., Matthiessen, B., Sommer, U., and Worm, B. (2014). Effects of sea surface warming on marine plankton. Ecol. Lett. 17, 614-623. doi: 10.1111/ele.12265

Li, W., Xu, X., Yao, J., Tanaka, N., Nishimura, O., and Ma, H. (2019). Combined effects of elevated carbon dioxide and temperature on phytoplanktonzooplankton link: a multi-influence of climate change on freshwater planktonic communities. Sci. Total. Environ. 658, 1175-1185. doi: 10.1016/j.scitotenv.2018. 12.180

Loick-Wilde, N., Fernandez-Urruzola, I., Eglite, E., Liskow, I., Nausch, M., SchulzBull, D., et al. (2019). Stratification, nitrogen fixation, and cyanobacterial bloom stage regulate the planktonic food web structure. Glob. Change Biol. 25, 794-810. doi: $10.1111 / \mathrm{gcb} .14546$

Lotze, H. K., Tittensor, D. P., Bryndum-Buchholz, A., Eddy, T. D., Cheung, W. W. L., Galbraith, E. D., et al. (2019). Global ensemble projections reveal trophic amplification of ocean biomass declines with climate change. Proc. Natl. Acad. Sci. U.S.A. 116, 12907-12912. doi: 10.1073/pnas.1900194116

Malzahn, A. M., Aberle, N., Clemmesen, C., and Boersma, M. (2007). Nutrient limitation of primary producers affects planktivorous fish condition. Limnol. Oceanogr. 52, 2062-2071. doi: 10.4319/lo.2007.52.5.2062

Malzahn, A. M., and Boersma, M. (2012). Effects of poor food quality on copepod growth are dose dependent and non-reversible. Oikos 121, 1408-1416. doi: 10.1111/j.1600-0706.2011.20186.x

Malzahn, A. M., Hantzsche, F., Schoo, K. L., Boersma, M., and Aberle, N. (2010). Differential effects of nutrient-limited primary production on primary, secondary or tertiary consumers. Oecologia 162, 35-48. doi: 10.1007/s00442009-1458-y

Marja, K., Wim Klein, B., and Nelleke, S. (1998). Effect of food quality on rate of growth and development of the pelagic copepod Pseudocalanus elongatus (Copepoda. Calanoida). Mar. Ecol. Prog. Ser. 170, 169-187. doi: 10.3354/ meps170169

Mathews, L., Faithfull, C. L., Lenz, P. H., and Nelson, C. E. (2018). The effects of food stoichiometry and temperature on copepods are mediated by ontogeny. Oecologia 188, 75-84. doi: 10.1007/s00442-018-4183-6

Mauchline, J. (1998). The Biology of Calanoid Copepods. San Diego: Academic Press.

Mayor, D. J., Anderson, T. R., Pond, D. W., and Irigoien, X. (2009). Limitation of egg production in Calanus finmarchicus in the field: a stoichiometric analysis. J. Mar. Syst. 78, 511-517. doi: 10.1016/j.jmarsys.2008.12.020

Mayor, D. J., Cook, K., Thornton, B., Walsham, P., Witte, U. F. M., Zuur, A. F., et al. (2011). Absorption efficiencies and basal turnover of $\mathrm{C}, \mathrm{N}$ and fatty acids in a marine Calanoid copepod. Funct. Ecol. 25, 509-518. doi: 10.1111/j.1365-2435. 2010.01791.x

Meunier, C. L., Boersma, M., Wiltshire, K. H., and Malzahn, A. M. (2016). Zooplankton eat what they need: copepod selective feeding and potential consequences for marine systems. Oikos 125, 50-58. doi: 10.1111/oik.02072

Müller-Navarra, D. (2008). Food web paradigms: the biochemical view on trophic interactions. Internat. Rev. Hydrobiol. 93, 489-505. doi: 10.1002/iroh. 200711046

Müller-Navarra, D. C. (1995). Biochemical versus mineral limitation in Daphnia. Limnol. Oceanogr. 40, 1209-1214. doi: 10.4319/lo.1995.40.7.1209

Müller-Navarra, D. C., Brett, M. T., Liston, A. M., and Goldman, C. R. (2000). A highly unsaturated fatty acid predicts carbon transfer between primary producers and consumers. Nature 403, 74-77. doi: 10.1038/47469

Müller-Navarra, D. C., Brett, M. T., Park, S., Chandra, S., Ballantyne, A. P., Zorita, E., et al. (2004). Unsaturated fatty acid content in seston and tropho-dynamic coupling in lakes. Nature 427, 69-72. doi: 10.1038/nature02210

Neila, A.-T., Nejib, D.-Y. M., Genuario, B., Lotfi, A., and Habib, A. (2012). Impacts of very warm temperature on egg production rates of three Acartiidae (Crustacea, Copepoda) in a Northern African lagoon. J. Therm. Biol. 37, 445-453. doi: 10.1016/j.jtherbio.2012.03.003 
Park, S., Brett, M. T., Müller-Navarra, D. C., and Goldman, C. R. (2002). Essential fatty acid content and the phosphorus to carbon ratio in cultured algae as indicators of food quality for Daphnia. Freshw. Biol. 47, 1377-1390. doi: 10. 1046/j.1365-2427.2002.00870.x

Parrish, C. C. (2009). "Essential fatty acids in aquatic food webs," in Lipids in Aquatic Ecosystems, eds M. T. Arts, M. T. Brett, and M. J. Kainz, (Heidelberg: Springer), 309-326. doi: 10.1007/978-0-387-89366-2_13

Passow, U., and Carlson, C. A. (2012). The biological pump in a high CO2 world. Mar. Ecol. Prog. Ser. 470, 249-271. doi: 10.3354/meps09985

Peck, M. A., and Holste, L. (2006). Effects of salinity, photoperiod and adult stocking density on egg production and egg hatching success in Acartia tonsa (Calanoida: Copepoda): optimizing intensive cultures. Aquaculture 255, 341350. doi: 10.1016/j.aquaculture.2005.11.055

Pommier, J., Frenette, J. J., Massicotte, P., Lapierre, J. F., and Glémet, H. (2012). Seston fatty acid composition and copepod RNA:DNA ratio with respect to the underwater light climate in fluvial Lac Saint-Pierre. Aquat. Sci. 74, 539-553. doi: 10.1007/s00027-011-0246-z

Provasoli, L. (1963). "Growing marine seaweeds," in Proceedings of the Fourth International Seaweed Symposium, eds A. D. De Virville, and J. Feldmann, (Oxford: Pergamon Press), 9-17.

Ravet, J. L., and Brett, M. T. (2006). Phytoplankton essential fatty acid and phosphorus content constraints on Daphnia somatic growth and reproduction. Limnol. Oceanogr. 51, 2438-2452. doi: 10.4319/lo.2006.51.5.2438

Rossoll, D., Bermúdez, R., Hauss, H., Schulz, K. G., Riebesell, U., Sommer, U., et al. (2012). Ocean acidification-induced food quality deterioration constrains trophic transfer. PLoS One 7:e34737. doi: 10.1371/journal.pone.0034737

Ruess, L., and Müller-Navarra, D. C. (2019). Essential biomolecules in food webs. Front. Ecol. Evol. 7:269. doi: 10.3389/fevo.2019.00269

Runge, J. A., and Roff, J. C. (2000). “The measurement of growth and reproductive rates," in Zooplankton Methodology Manual, eds R. Harris, P. Wiebe, J. Lenz, H. R. Skjoldal, and M. Huntley, (London: Acadamic Press), 401-454. doi: 10. 1016/b978-012327645-2/50010-4

Saiz, E., Calbet, A., Fara, A., and Berdalet, E. (1998). RNA content of copepods as a tool for determining adult growth rates in the field. Limnol. Oceanogr. 43, 465-470. doi: 10.4319/lo.1998.43.3.0465

Santer, B., and van den Bosch, F. (1994). Herbivorous nutrition of Cyclops vicinus: the effect of a pure algal diet on feeding, development, reproduction and life cycle. J. Plankton Res. 16, 171-195. doi: 10.1093/plankt/16.2.171

Schälicke, S., Sobisch, L. Y., Martin-Creuzburg, D., and Wacker, A. (2019). Food quantity-quality co-limitation: interactive effects of dietary carbon and essential lipid supply on population growth of a freshwater rotifer. Freshw. Biol. 64, 903-912. doi: $10.1111 /$ fwb. 13272

Sharp, J. (1974). Improved analysis for particulate organic carbon and nitrogen from seawater. Limnol. Oceanogr. 19, 984-989. doi: 10.4319/lo.1974.19.6.0984
Sommer, U. (1992). Phosphorus-limited Daphnia: intraspecific facilitation instead of competition. Limnol. Oceanogr. 37, 966-973. doi: 10.4319/lo.1992.37.5.0966

Sommer, U., Stibor, H., Katechakis, A., Sommer, F., and Hansen, T. (2002). Pelagic food web configurations at different levels of nutrient richness and their implications for the ratio fish production: primary production. Hydrobiologia 484, 11-20. doi: 10.1023/a:1021340601986

Sterner, R. W., and Elser, J. J. (2002). Ecological Stoichiometry: The Biology Of Elements From Molecules To The Biosphere. Princeton: Princeton University Press.

Sterner, R. W., and Robinson, J. L. (1994). Thresholds for growth in Daphina magna with high and low phosphorus diets. Limnol. Oceanogr. 39, 1228-1232. doi: 10.4319/lo.1994.39.5.1228

Sterner, R. W., and Schulz, K. (1998). Zooplankton nutrition: recent progress and a reality check. Aquat. Ecol. 32, 261-279. doi: 10.1023/A:1009949400573

Straile, D. (1997). Gross growth efficiencies of protozoan and metazoan zooplankton and their dependence on food concentration, predator-prey weight ratio, and taxonomic group. Limnol. Oceanogr. 42, 1375-1385. doi: 10.4319/lo.1997.42.6.1375

Taipale, S. J., Kainz, M. J., and Brett, M. T. (2011). Diet-switching experiments show rapid accumulation and preferential retention of highly unsaturated fatty acids in Daphnia. Oikos 120, 1674-1682. doi: 10.1111/j.1600-0706.2011.19415.x

Urabe, J., and Watanabe, Y. (1992). Possibility of N or P limitation for planktonic cladocerans: an experimental test. Limnol. Oceanogr. 37, 244-251. doi: 10.4319/ lo.1992.37.2.0244

Van Nieuwerburgh, L., Wänstrand, I., and Snoeijs, P. (2004). Growth and $\mathrm{C}: \mathrm{N}: \mathrm{P}$ ratios in copepods grazing on $\mathrm{N}$ - or Si-limited phytoplankton blooms. Hydrobiologia 514, 57-72. doi: 10.1023/B:hydr.0000018206.02271.2b

Wendt, I., and Thor, P. (2015). Influence of prey species and concentration on egg production efficiency and hatching success in Acartia tonsa Dana (Copepoda, Calanoida). Crustaceana 88, 675-687. doi: 10.1163/15685403-00003436

Yebra, L., Kobari, T., Sastri, A. R., Gusmao, F., and Hernandez-Leon, S. (2017). Advances in biochemical indices of zooplankton production. Adv. Mar. Biol. 76, 157-240. doi: 10.1016/bs.amb.2016.09.001

Conflict of Interest: The authors declare that the research was conducted in the absence of any commercial or financial relationships that could be construed as a potential conflict of interest.

Copyright $(2020$ Bi and Sommer. This is an open-access article distributed under the terms of the Creative Commons Attribution License (CC BY). The use, distribution or reproduction in other forums is permitted, provided the original author(s) and the copyright owner(s) are credited and that the original publication in this journal is cited, in accordance with accepted academic practice. No use, distribution or reproduction is permitted which does not comply with these terms. 